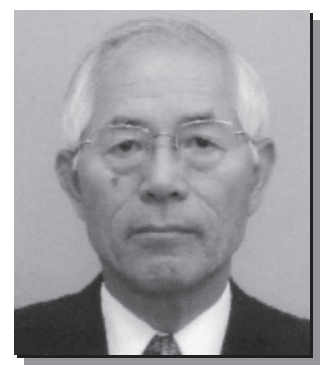

山本英幸君は昭和 40 （1965）年名古屋大学工学部応用物理学科を卒業後, 直ちに株 式会社ダイヘンに入社した。 その後, 昭和 63 (1988) 年に溶接機事業部・研究開発部 長, 平成 2 年 (1989) 年に溶接機事業部 - 商品企画部長, 平成 5 （1993）年に溶接機事 業部・技術部長を歴任し, 平成 10 (1998) 年に溶接機事業部長, 平成 11 (1999) 年に 取締役・溶接メカトロ事業部長平成 13 (2001) 年に取締役常務執行役員・溶接メカト ロカンパニープレジデントから平成 15 (2003) 年に取締役専務執行役員・溶接メカト ロカンパニープレジデントに就任し, 平成 17 (2005) 年からダイヘン溶接メカトロシ ステム株式会社・代表取締役社長を経て現在に至っている。

この間，一貫して溶接・切断機器の研究及び技術開発部門において，アーク溶接技 術及びプラズマ切断技術の基礎研究と, 制御技術の開発に従事し, 数多くの新溶接法及び新溶接機器の開発 を行い, この分野の進歩, 発展, 向上に寄与した.

同君はこれらの開発にあたって, アーク放電現象, 溶滴移行現象などの基礎研究を基に卓越した洞察力と 斬新なアイデアにより多くの業績をあげた。特に昭和 50 年代半ばに入って, 大電流パワートランジスタが開 発されると同時に, トランジスタインバータの高速制御性にいち早く着目し, 各溶接プロセスのアーク現象 に応じたさまざまな電流制御方法を開発し，アーク溶接機器の性能の大幅な向上に成功し，アーク溶接技術 の革新と溶接の自動化，省力化に大きく貢献した.

これらの成果は, “超高速インバータ制御 $\mathrm{CO}_{2}$ アーク溶接機の開発”において電子リアクトル制御法を始め とする新波形制御法による溶接機器の性能の大幅な向上に成功し, 昭和 60 (1985) 年には新技術開発財団より 『市村賞貢献賞』が授与されている。また，昭和 63 (1988) 年には “ダブルインバータ制御式交直両用 TIG 溶 接機の開発と実用化” で『日本溶接協会技術賞』が，平成 5（1993）年には “ファジイ制御 MIG 溶接機の開 発と実用化”で，『日本溶接協会技術賞』が授与されている。さらに平成 6（1994）年には“低周波パルス MIG 溶接法の研究開発”で『軽金属溶接構造協会論文賞』が授与されている.

またこの間，エアプラズマ切断機の国産化をはかり，小電流から大電流のエアプラズマ切断機の製品化を 進め普及に努め，わが国の金属切断作業の高能率化，高品質化に貢献した役割も特筆される.

以上の功績により平成 14 (2002) 年には『溶接学会佐々木賞』が授与されている.

一方同君は, 以上の業績に加えて, 溶接学会に押いては, 副会長 (平成 18 (2006) 年〜平成 19 (2007) 年) をはじめとして理事 3 期 (平成 8 (1990) 年〜平成 13 (1993) 年), 代議員（評議員）4 期 (平成 2 (1990) 年〜 平成 5 （1993）年および平成 10 (1998) 年〜平成 13 (2001) 年), 関西支部支部長および溶接アーク物理委員会 委員長を歴任した。また，平成 13 (2001) 年に開催した第 7 回国際溶接シンポジウム (神戸) 㧍よび平成 20 (2008) 年に開催した第 8 回国際溶接シンポジウム (京都) では財務委員長として国内・海外の参加者を多数集 めるなど，溶接学会が主催する国際イベント成功に貢献するなど, 学会の運営と発展に貢献した.

以上のように，山本英幸君の溶接学会に対する長年の功績は非常に大なるものがある. 


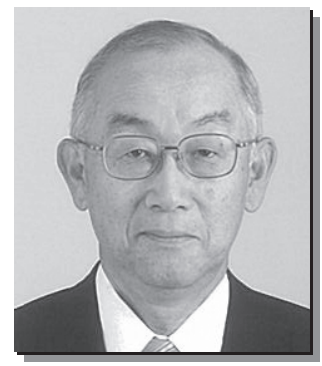

中川幸也君は昭和 41 (1966) 年に東北大学・工学部・金属工学科を卒業後 (米) デ ラウェア大学・工学部・大学院に進み, 博士課程を修了後カナダルトント大学・工 学部・金属治金学科研究員を経て昭和 48 (1973) 年に石川島播磨重工業（株，当時） 技術本部金属部に入社した。その後平成 2（1990）年に技術本部・技術研究所・高性 能材料部部長，平成 8 （1996）年に技術本部 - 管理部長，平成 10 (1998) 年に技術研 究所所長, 平成 11 年 (1999) 年に技術開発本部副本部長を歴任し, 平成 13 (2001) 年 に取締役，平成 15 (2003) 年に常務執行役員・技術開発本部本部長，平成 17 (2005) 年に副社長執行役員から代表取締役副社長に就任し, 平成 20 (2008) 年からの取締役 を経て現在に至っている.

同君の研究者としての大きな業績は, ジェットエンジン・タービンブレードに利用されている超合金に関 しての研究開発である．同君は金属物理学的解析により組織制御理論を構築し，その高温特性の改善を図る とともに，一方向凝固組織㧍よび単結晶組織を付与する精密鋳造技術を確立した．IHI (現在)のジェットエ ンジン事業に大きく貢献するとともに，社外ではこの業績で科学技術庁長官賞 (平成 7 年 (1995) 年) を受賞 している.

そのほかにも, 高温クリープ挙動を転位組織から考察した高度な学術的理論を多々発表し, 国内外に高く 評価されている。また，耐熱合金では，ODS 合金をはじめプロセス設計および固相拡散接合技術の開発を行 ったほか，低圧タービンブレード用 TiAl 合金の精密鋳造技術の開発など，とくにジェットエンジンの高温材 料関係で多くの顕著な業績がある. 上述の賞のほかに, 第 6 回スーパーアロイ国際学会最優秀論文賞 (AIME 主催, 昭和 63 (1988) 年), (社) 日本金属学会功績賞 (平成 2（1990）年), (社) 日本金属学会技術開発賞 (平 成 2（1990）年）を受賞している.

管理部長〜技術研究所所長〜技術開発本部本部長時代は研究マネジメントに注力し, 生産技術センターが 担当する溶接関係部門と技術研究所の材料研究部門㧍よび構造強度研究部門などの関係部門との連携を深め た.

同君は創立 80 周年の平成 18 (2006) 〜平成 20 (2008) 年に溶接学会会長を務めた。企業からの会長は平成 12 (2000) 〜 13 (2001) 年度以来である. 溶接学会は企業の賛助員と個人会員が基盤を支えているが，経営者 としての観点から最初に取り組んだのは財政強化であり，平成 14 (2002) 年以来赤字体質が続いていたのを黒 字化を達成した。また，活性化にも積極的に取り組み，溶接協会，産報出版との連携による「溶接連合講演 会」を立ち上げた。会長時代には溶接学会論文集の WEB 化も行い，論文掲載料の引き下げによる会員サー ビスと経費削減の両面を達成した。さらに，平成 20 (2008) 年春には全国大会を大阪で国際ウェルディングシ ヨーとの同時開催を成功させたほか, 成功裏に終わった $8 \mathrm{WS}$ (第 8 回国際溶接シンポジウム) の開催決定と準 備をスタートさせた。ホームページの充害など学会の活性化も進みつつある.

以上のように, 中川幸也君の溶接学会に対する功績は非常に大なるものがある. 


\section{アーク溶接現象の定量化と厚板溶接構造物の ための溶接技術指針の提言}

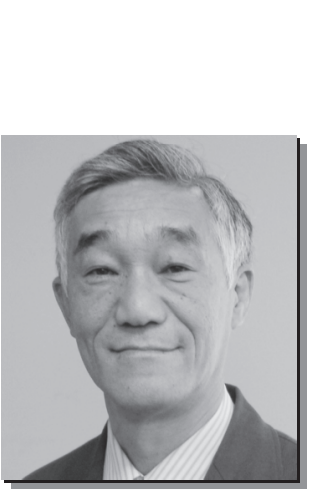

正員 平岡 和 雄 君

平岡和雄君はこれまで一貫してアーク溶接とその物理現象解明について研究を行 い，基礎現象から応用にわたる広い分野で優れた業績をあげ，同分野の発展に貢献し た.

まず，研究活動では，溶接アークプラズマ熱源特性の計測・解析技術開発を通し て, アーク溶接現象の定量化を推し進めてきた．特筆すべき研究としは，アーク溶接 で色々の状況において混合ガスがシールドガスとして用いられるが，混合ガス䨌囲気 に打ける溶接アーク現象に打いて, 二線強度相関分光分析法を開発して新規にデミキ シング (プラズマガス中のガス組成不斉一) 現象を発見し，同時に溶接アーク熱源の 温度や組成などの定量的な構造を明らかにしてきた。このことは混合ガスシールドア ーク現象の理解を深めるとともに従来考えられていたアークプラズマ中での熱物質輸送の理論的取り扱いを 見直す機会を与えた。

次いで, $800 \mathrm{MPa}$ 級微細粒高強度鋼を対象として溶接変形，残留応力や母材熱影響部を抑制ための小入熱 でも高効率な厚板溶接を指向し, 従来不可能とされていた開先間隙 $5 \mathrm{~mm}$ 以下の厚板狭開先アーク溶接（超狭 開先アーク溶接）を提案し，それを具現化して見せた。この研究においてもアーク現象を定量化したモデル による数值シミュレーション技術を開発し，この数值シミュレーションを活用して高効率の溶接制御技術が 新しく開発できることを実証した。この一連の研究も溶接プロセス開発の今後のあり方を提示するものであ る.

その後, 溶接における総合研究に視点をおき, 小入熱の新溶接法での急熱・急冷熱サイクルにおいても「母 材並の高強度溶接継手をどのようにすれば形成できるか」を探求してきた，高強度鋼での課題には，母材で の HAZ 勒性改善と, 溶接金属での水素による低温割れ抑止扔よび鞁性改善があるが，HAZ 鞁性改善に対し ては Al-Si を添加した高強度微細粒鋼を提案し，溶接金属の低温割れ対策に関しては，低炭素当量設計概念と は異なる残留オーステナイト活用による水素トラップを提唱してきた。また $800 \mathrm{MPa}$ 超級の高強度溶接金属 では，含有酸素を母材並に極隇化 (クリーン化) できるNIMS ハイブリッド溶接ワイヤを提案して，マルテン サイト系 as weld 溶接金属で高靱性を達成し，従来のオキサイドメタラジーに替わる clean-weld metallurgy を提唱し，溶接材料設計にも言及してきた。これらの斬新な提案は，平成 19 年度から開始された「鉄鋼材料 の革新的高強度・高機能基盤研究開発」NEDO プロジェクトの提案骨子として採択され, 本プロジェクトに おける溶接技術課題のリーダーを務めている.

上記のように同君は, 深い洞察力をもって新提案とその検証を実行し, 溶接研究の活性化に大いに貢献し ている.

一方, 溶接学会では理事 3 期, 副会長，監事，企画委員会委員長，論文査読審査委員会委員長，溶接情報 化委員会委員長, 溶接学会の溶接アーク物理研究委員会委員長, 編集委員会委員等の重責を歴任し, また日 本溶接協会では評議員や総務委員会副委員長を歴任すると伴に，その他にも国際溶接会議では理事 2 期や, 再処理施設専門部会委員など国内外の溶接技術の発展に大きく貢献している.

以上のように同君の溶接関連分野に対する貢献は多大である. 


\section{高エネルギービーム溶接現象の解析とプロセス制御}

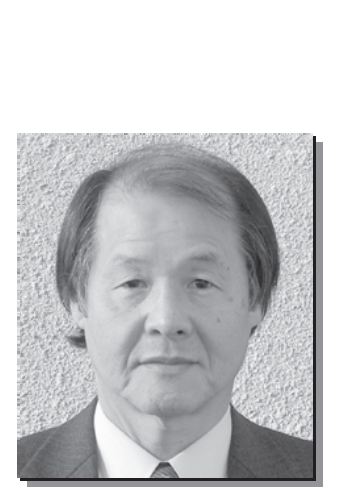

正員 塚本進君

塚本進君の主な研究は, 高エネルギービーム溶接現象の解析と, そのプロセス制 御に関するものである. 特に厚板溶接時に発生する溶接欠陥の機構解明と, 斬新な 欠陥防止技術の開発に優れた研究成果を残している.

電子ビーム溶接においては，電子ビーム照射位置から発生するX 線及び熱電子の 挙動を解析することにより，材料の溶融過程を明らかにすると共に，これと溶融金 属の流動・凝固挙動との関連を明確に示した。またその基礎的な成果をもとに，八 ンピングビード，ポロシティ，凝固割れ，スパイク等，厚鋼板の溶接部で見られる 各種溶接欠陥の形成機構を明らかにした。さらに，4極子コイルにより電子ビーム の断面形状を制御する新しい手法を提案し，そのフィードバック制御により，形成 機構が異なる数種の溶接欠陥を同時に防止することに成功した。これらの成果は，我が国が世界をリードし てきた電子ビーム溶接の実用化に対して大きな貢献をした.

レーザ溶接においては, 独自に開発した画像分光法によりレーザ誘起プルームの精密な温度計測を行い, レーザとプルームの相互作用を明確にした。また，in-situ X 線透過撮影によりキーホールの動的な挙動を観 察し, 部分溶け达み溶接時に発生するポロシティが, 細長いキーホールの不安定現象によることを明らかに した，さらに，キーホールを安定化する手段としてレーザの出力変調を提案し，溶融池の固有振動周波数を 用いることによりキーホールが安定化し，これによりポロシティの発生が大幅に抑制できることを実証した. 厚板の貫通溶接に扔いては，ポロシティが溶融池内に過飽和に溶解した窒素により形成されること，これを 防止するため裏面を不活性ガスでシールドすると，不活性ガスがキ一ホールを大きく乱し，凝固割れの発生 を助長することなどを明らかにした。また，これら両欠陥を同時に防止する手段として脱窒素元素を溶融池 に添加することが有効であることを示した。レーザ/アークハイブリッド溶接においては，レーザプルーム とアークの相互作用を解析し，相互作用が必ずしもアークの安定化に寄与しない場合があることを示した. また，プラズマ気流とマランゴニ対流の制御により，フイラーワイヤを均質に分布する手法を提案した。

その他，超微細粒高強度鋼，高窒素ステンレス鋼，マルエージ鋼等の高エネルギービーム溶接部の組織解 析，レーザ溶接部の鞁性評価法の提案，電子ビームを用いた急冷凝固現象の解析，電子ビーム照射による超 電導線材の創製等，高エネルギービーム溶接部の組織・特性評価や新しい高エネルギービームプロセスの提 案にも優れた成果を挙げている.

これらの研究業績に対して，溶接学会溶接論文賞，日本金属学会論文賞，日本鉄鋼協会白石記念賞，科学 技術庁注目発明が授与されている.

また，溶接学会では，東部支部長，高エネルギービーム研究委員会副委員長，溶接治金研究委員会幹事， 編集委員会委員, 論文查読・審査委員会委員, 研究推進委員会委員, 全国大会運営委員会委員などを, 日本 溶接協会では，レーザ加工技術研究委員会幹事，表面改質研究委員会幹事，宇宙機用溶接技術研究委員会委 員などを, レーザ加工学会では, 評議員, 論文査読委員などを歴任している.

以上のように，塚本進君の業績は溶接関連分野の発展に大きく貢献している. 
溶接継手の破壊性能評価のための破壊勒性評価手順の研究

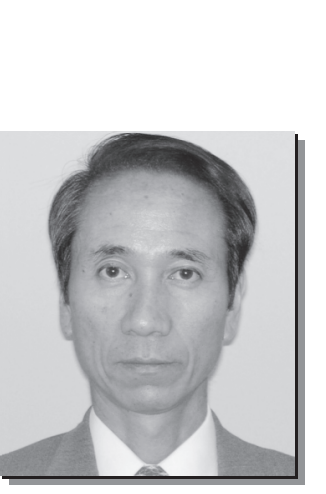

正 員 南 二三吉 君

南二三吉君の研究は, 溶接強度力学ならびに溶接破壊力学を軸とする構造強度評 価工学の分野に扔いて優れた業績をあげている.とくに, 溶接構造物の健全性・安 全性確保に不可欠な不安定破壊（脆性破壞）を防止する技術の体系化においては，国 内はもとより世界的にも先駆的研究者として名声を博している. 例えば，溶接部に 不可避な局所的な材質劣化や強度的不均質といった材質不均質がいかに破壊特性に 影響するかについて一連の研究を行っており，材質不均質の存在を力学的のみなら ず確率統計的に捉えることで溶接部破壊勒性值の意義を明確にし, 構造性能評価に 反映すべき先駆的なアイデアを数多く提案しており，その成果は，日本溶接協会規 格WES1108 拈よびWES 1109 に骨格として取り入れられている.

一方, ノースリッジ地震, 阪神淡路大地震において建築鉄骨構造に未曾有の脆性破壊が引き起されたこと は記憶に新しいが,「動的負荷」や「大変形繰返し負荷」といった大規模地震下特有の負荷様式が破壊勒性に 及ぼす影響の解明に世界に先駆けて取り組み，「遷移温度アプローチ」を提案することで, 破壊勒性に及ぼす 動的・繰返し大変形効果を統一的に扱えることを明らかにした。これにより, 大規模地震下での構造性能を 評価する手法の骨格が構築され, 我国において「動的繰返し大变形を受ける溶接構造物の脆性破壊性能評価 方法 (日本溶接協会規格 WES 2808)」の制定に多大な貢献をしたことは周知のとおりである.

さらに, 近年の合理的な構造破壊性能評価の要求や，構造性能に見合った適切な材料要求勒性を決定する という要求に応えるべく, 従来の破壊力学手法を拡張した新しい破壊評価法として, ワイブル応力と呼ばれ る新たな破壊駆動力を適用した手法の展開に精力的に取り組んできた。破壊に先立つ塑性変形が大きくなる と, 破壊勒性試験で得られる情報をそのまま構造性能評価に適用すると, その性能を過度に小さく見積もる 傾向がある。これは, 破壞勒性試験片と構造部材との塑性拘束の差異によるもので, ワイブル応力を活用す ることでこの拘束差を補正する「等価 CTOD 係数 $\beta$ 」を世界で初めて提案し, 破壊勒性試験結果を合理的に 溶接構造性能評価へ結び付ける Fracture Transferability 評価技術を確立している.この成果を, 経済産業省 基準認証研究開発事業「鉄鋼材料の破壊勒性評価手順の標準化」として展開し, 我国初の鉄鋼材料に関わる 国際規格 ISO 規格（ISO/FDIS 27306）の制定に向けた活動へと発展させ, 現在, 欧米諸国からの合意が得ら れその最終段階に到達している。 また, ワイブル応力を適用した破壊評価技術を，レーザ溶接継手などの溶 接部へ適用，さらに高強度鋼の水素割机感受性の新たな評価手法へも展開している.

このように, 南二三吉君は, 溶接力学, 破壊力学を基礎として独自の破壊評価学を構築し, 溶接構造物の 合理的な破壞性能の評価法や設計法を確立するとともに, 我国の強みである高強度鋼材やその溶接材料の 益々の適用拡大が期待される多大な成果を挙げており，鉄鋼業界，溶接界のみならず我国の産業界に大きく 貢献している。 また, 溶接学会では, 理事, 編集委員会委員長, 溶接構造研究委員会委員長, 溶接情報化委 員会委員長など, 各種委員会の委員長・幹事長を歴任し，日本溶接協会では鉄鋼部会幹事や化学機械溶接研 究委員会などの委員長を務めるなど，溶接界に大きく貢献している. 


\section{传名裳}

\section{溶接材料の進歩、発展ならびに後進の 指導・育成に貢献した功績}

\section{正 員 黒 川 剛 志 君}

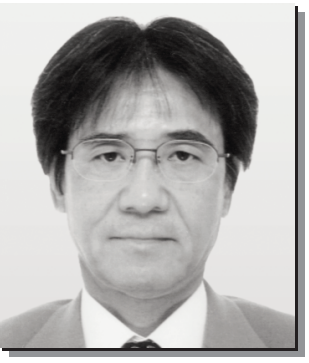

した.

次に，ステンレス鋼用溶接材料の分野に打いて，優れたフラックス入りワイヤ（以下，FCW）を開発・実用 化し, 高能率化と高品質化を求める産業界の要求に応えた。特に, 混合ガス用を欧州向けに, 全姿勢用を北 米向けに開発し，世界的なレベルで FCW 化を大いに進展させた。

さらには，治金的な析出現象の観点からも注目される PWHT 仕様チタニヤ系 FCW の開発・実用化が挙げら れる. チ夕ニヤ系 FCW による溶接金属の SR 脆化の原因が, 微細な NbC や VC の析出が主因であることを 世界で初めて解明し, 新しい設計思想に基づく FCW を開発した。 開発製品は化工機や圧力容器等の市場に提 供され，高い評価を受けている。

環境の観点からは，ヒューム及びスパッタの発生量を大幅に低減させた新しい夕イプの炭素鋼用 FCW を開 発・実用化している。これは，外皮金属の $\mathrm{C}$ 低減などの低ヒューム化技術や，アルカリ金属の添加などのフ ラックス組成の最適化などの技術により達成したものであり，溶接作業環境の改善に大きく寄与している.

また，特筆すべき事績としては，高性能銅めっきなしソリッドワイヤの開発・実用化がある。これは，給 電電極の摩耗機構，溶滴形成，移行過程，送給性などについて基礎的考察を十分に行った上で，銅めっきに 替わるワイヤ表面処理技術を構築して，アーク安定性やワイヤ送給性に優れた当該ワイヤを開発したもので ある. 生産過程で環境負荷の大きいめっき工程をなくしたことも含め, 産業界の広い分野で環境改善ならび に能率向上に貢献している.

これらの業績は, 学協会から高く評価され, 日本溶接協会・溶接注目発明賞, 溶接学会・田中亀久人賞, 日本金属学会・技術開発賞, 発明協会・近畿地方発明表彰奨励賞をはじめ多数の賞を授与されている.

また, 学協会活動として溶接学会理事, 同評議員, 日本溶接協会国際活動委員会幹事などの職務を務め, その活動は一企業内に止まることなく，わが国の溶接界全体に幅広く貢献している.

以上に記載の如く，同君は溶接材料に関する研究・開発で顕著な業績を残し、溶接技術の進歩発展に大いに 寄与してきた。また、経歴の職位にあって後進技術者の指導・育成にも努め，多くの業績を残してきた．更 に, 学協会などの公的な活動を通じ, 溶接界全体のレベルアップにも積極的に尽力しており, その功績は極 めて顕著である.

\section{略}

歴

昭和 27 年 2 月 11 日生

昭和50年 3 月 早稲田大学 理工学部 機械工学科 卒業

昭和 50 年 4 月 (株神戸製鋼所 入社

平成 2 年 1 月 侏神戸製鋼所 溶接棒事業部 技術部 主任研究員

平成15年 4 月 溶接カンパニー 技術開発部長

平成18年 6 月 溶接カンパニー 技術開発部長 兼溶接カンパニー 藤沢事業所長

平成19年 4 月 侏) セト 常務取締役 現在に至る 


\title{
恢々 木尊
}

\section{鉄鋼製品の溶接技術の進歩・発展ならびに 後進の指導・育成に貢献した功績}

\author{
正員 安田功 一 君
}

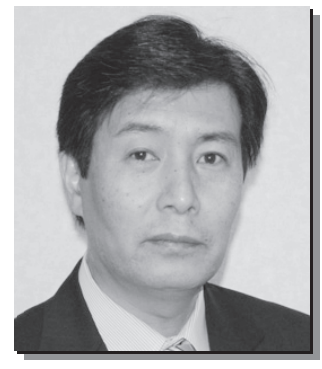

安田功一君は，川崎製鉄（株）に入社以来，現在に至るまで一貫して研究所にて鉄 鋼材料の溶接技術の研究開発に従事し, 自動車用薄鋼板から造船, 圧力容器用極厚 鋼材に至るあらゆる鉄鋼材料の溶接に関して，溶接材料および溶接熱影響部の材質 変化を基にした鋼材開発，溶接プロセスの開発・実用化に取り組み，鉄鋼材料の適 用・応用技術の進歩と発展に大いに寄与した。また溶接学会に执いては，本部，支 部，各種委員会等の役職を歴任し，その豊富な経験と優れた専門性と指導力を生か して多くの優秀な溶接技術者を指導育成してきた。

業績は多岐にわたるが，その主な業績は次のとおりである.

1）自動車用薄鋼板の抵抗スポット溶接技術掞よび覀鉛めっき鋼板のアーク溶接技術

の開発

薄板の溶接技術分野では，抵抗スポット溶接現象に及ぼす電極先端形状，加圧力の影響を解明し，連続打 点中の電極保有熱量，先端部温度分布を明確にして電極寿命を考虑した带鉛めっき鋼板を開発した。また溶 接中に電流と加圧力を段階的に変化させることによって鋼板板厚方向の発熱分布を制御し, 溶接可能な板厚 比を大幅に拡大できる三枚重ね溶接方法を開発した。また Laser 溶接 TWB 材の成形性を継手の機械的性能 の観点から調査し，成形性に優れた TWB 材の指針を提案した．亜鉛めっき鋼板のアーク溶接分野では溶接時 に発生するブローホール発生現象を解明し，気泡発生を抑制する溶接方法や気泡防止剂を開発するなど，薄 鋼板の加工利用技術に貢献した.

2）低スパッタ $\mathrm{CO}_{2}$ アーク溶接ワイヤの開発と Spray 移行型 $\mathrm{CO}_{2}$ アーク溶接方法の開発

厚板用沉用ガスメタルアーク溶接材料の開発においては, ワイヤ中の $\mathrm{K}, \mathrm{REM}$ などの微量添加元素, 表面 性状, 高周波パルス印加, 電源極性などの影響を明確にし, 従来にない K 添加による極低スパッタワイヤと その連続的製造方法を開発するとともに, REM 添加ワイヤと正極性を組合わせることによって, 低スパッ夕 化は勿論, 従来の $\mathrm{CO}_{2}$ アーク溶接では有り得なかった Spray 移行を可能にした $\mathrm{CO}_{2}$ アーク溶接方法を開発す るなど厚板鉄鋼製品への新しい GMAW 溶接方法の適用・応用技術に貢献した。

3）圧力容器内面ステンレス肉盛溶接技術の開発と肉盛溶接部の割れ現象に関する研究

厚板の溶接技術分野では, 圧力容器内面ステンレス肉盛溶接技術に扔いて, 広幅帯状電極を用いたオーバ ーレイ溶接材料を開発するとともに肉盛溶接部に発生する SR 熱処理時のクラッド下割れ (SR-UCC), 肉盛 溶接時の水素に起因したクラッド下割れ（水素-UCC，，および高温・高圧水素環境下での使用中に発生する クラッド剥離割れ (Disbonding) 現象を解明してこれらの課題解決手法および鋼材を提案，開発した。

4）鋼管の溶接技術

鋼管の溶接技術分野では，UOE 鋼管のシーム SAW 溶接において高強度高勒性溶接材料を開発し，また高 能率円周溶接技術を開発した，とくにステンレス鋼管の溶接では， REM 添加溶接ワイヤによる $12 \mathrm{Cr}$ 用純不 活性ガス MIG 溶接ワイヤを開発して業界初の共金系高勒性溶接技術を確立し，また二相 SUS 鋼溶接継手部 の $\gamma / a$ 率を化学組成と溶接熱サイクルにより予測する手法を開発して溶接継手部の耐食性能支配因子を明確 にするなど鋼管材質の進歩に対応した利用拡大技術の開発に貢献した。

5）厚鋼板の溶接技術

厚鋼板の溶接技術分野では，建築構造用極厚鋼板ボックス柱の大入熱高能率 SAW 角溶接や大入熱 ESW ダ イヤフラム溶接などの超大入熱溶接プロセスにける溶接金属, 溶接 HAZ の高勒性組織制御を可能にした溶接 材料抢よび鋼板を開発した。とくに HAZ 勒性の高勒化に関して, 溶接中の溶接 $\mathrm{t}$ 金属から HAZへの B 拡散 を利用した手法は従来に無いアプローチとして注目された。また，厚板への Laser 溶接適用技術分野におい ても，業界に先駆けて冶金学的見地から研究を進め，勒性評価時の Fracture Path Deviation の問題提起と微 小衝撃試験法による評価との相関明らかにするとともに，Laser 溶接金属の Acicular 組織が現出する組成・ 冷却速度範囲を明確にしその組織の特徵と優れた機械的性能を示して高強度 Laser 溶接金属への適用・応用 を提案した。また低変態温度溶接材料を用いた溶接継手疲労強度向上技術を確立するとともにこれを応用し た溶接変形軽減技術に関して国家PJを提案し，溶接変形軽減溶接材料の基本設計指針を提案した. 
6）後進の溶接技術者の指導・育成

溶接学会では理事会, 企画委員会, 東部支部などにおいて, 会勢拡大, 学会活性化活動および財務強化施 策に注力し, 溶接学会東部支部技術セッションや実用溶接講座など会員にとって魅力ある見学講習会を企 画・立案するとともに, 溶接・接合工学振興会などのセミナー講師を通して溶接技術者の教育・育成に貢献 している. また溶接学会, 日本溶接協会などの各種研究委員会や部会などでは積極的な委員会活動を通して 教育・指導的立場から溶接技術者, 溶接研究者の研究開発活動を活性化し, 後進の指導ならびに産業界の活 性化に貢献している。

\section{略歴}

1954年 1 月 24 日生

1976年 3 月 大阪大学 工学部 溶接工学科 卒業

1978年 3 月 大阪大学大学院 工学研究科 溶接工学専攻 修了

1978年 4 月 川崎製鉄株) 入社，技術研究所 厚板研究部 溶接研究室

1984年10月 川崎製鉄(株) 技術研究所 厚板研究部 溶接研究室，主任研究員

1991年10月＼cjkstart英国 The Welding Institute 留学（ 2 年間）

2001年 7 月 川崎製鉄(株) 技術研究所 厚板 - 条鋼 ・ 接合研究部, 主任研究員 (部長)

2003年 4 月 JFE スチール(株) スチール研究所 接合・強度研究部, 部長

2005年11月 大阪大学 博士 (工学) 学位取得

2007年 4 月 JFE スチール(株) スチール研究所，主席研究員 現在に至る 


\section{平成20年度 涳接学会签文賞}

\section{T継手部の脆性き伝播停止挙動に及ぼす未溶着寸法の影響}

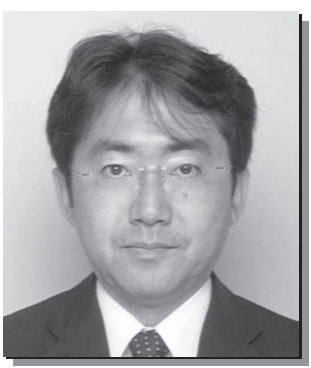

半田恒久君

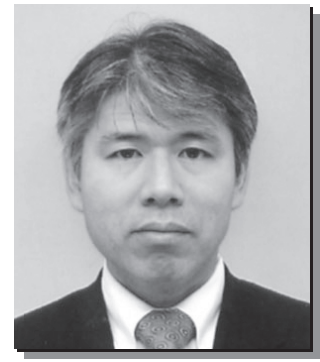

鈴 木 伸 一 君



木治昇君



豊 田昌信 君
近年コンテナ船の大型化に伴い高強度鋼厚板が使用され，効率のため大入熱溶接 法の適用が望まれる。その設計・施工においては脆性破壊を生じさせない材料選定 および溶接施工が行われるが，万が一主要部材であるハッチコーミングの大入熱溶 接継手に脆性破壊が発生・伝播した場合に，脆性き裂をどの部位でいかに停止させ るかがコンテナ船の設計, 施工上の課題とされている。とくに, 厚板では溶接部に 生じた脆性き裂は母材に逸れることなく溶接部を伝播するとの実験に基づいた報告 がなされ，これを問題視した日本海事協会 (NK) では業界, 学術界の専門家を集め た検討が行われている.

著者らはハッチコーミングとデッキプレートとの T 継手部材にすみ肉溶接または 未溶着を有する溶接継手を適用することにより脆性き裂停止特性を持たせることを 検討した。著者らが提案した独自の大型モデル実験によれば，完全溶达溶接継手で は脆性き裂が停止することなく破断したが，適度のサイズの不溶着を有する不完全 溶込溶接継手およびすみ肉溶接継手では脆性き裂が停止し，その有効性を証明した. さらに，き裂停止メカニズムについても，破壊力学的考察を行っている．本論文で 得られた知見は船体構造の破壊安全性に対して有用であり, すみ肉溶接構造は「構 造アレスト設計」と呼ばれて実船にも適用された。

近年久しぶりに破壊問題を取り扱った論文であり，実験と解析がバランスよく組 み合わされているとともに，破壊問題の解決法を示唆した優れた論文と判断する. また，学分野のみならず材料，施工・管理，品質保証・品質管理の各分野にまたが る論文でもあり，学術的，工業的にも寄与するところが大きい.

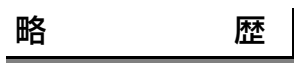

半田恒 久

1966年10月 6 日生

1989年 3 月 東京農工大学工学部機械工学科卒業

1991年 3 月 東京農工大学大学院工学研究科博士前期課程修了

1991年 4 月 川崎製鉄株式会社（現 JFE スチール株式会社）入社

2003年 4 月 JFE スチール株式会社スチール研究所主任研究員 現在に至る

鈴木伸一

1961年10月20日生

1985年 3 月 東京大学工学部金属工学科卒業

1985年 4 月 日本鋼管株式会社 (現 JFE スチール株式会社) 入社

1985年 5 月 同 中央研究所第一材料研究部研究員

1992年 8 月 イギリス ケンブリッジ大学留学

1994年 8 月 日本鋼管株式会社 (現 JFE スチール株式会社) 総合材料研究所 主任 研究員 


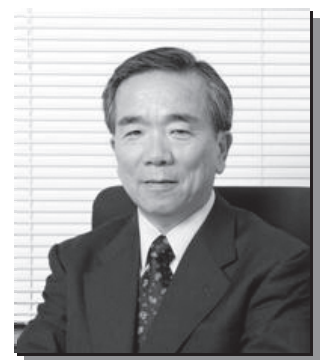

宮田隆司君
2003年 4 月 JFE スチール株式会社スチール研究所主任研究員 現在に至る

木治昇

1969年 6 月 27 日生

1992年 3 月 大阪府立大学工学部金属工学科卒業

1994年 3 月 大阪府立大学大学院工学研究科金属工学専攻修士課程修了

1994年 4 月 石川島播磨重工業株式会社（現 株式会社 IHI）入社 技術本部技術研究 所接合部配属

2001年 4 月 石川島検查計測株式会社 (現 株式会社 IHI 検查計測) 研究開発事業部 2003年 4 月 石川島播磨重工業株式会社（現 株式会社 IHI）技術開発本部生産技術七 ンター 生産技術開発部

2007年 4 月 株式会社アイ・エイチ・アイマリンユナイテッド 吳工場工作部生産 計画グループ

2008年 4 月＼cjkstart吳工場生産・システム技術部主查＼cjkstart現在に至る

豊 田昌 信

1969年 8 月 22 日生 技術士 (船舶・海洋部門)

1994年 3 月 九州大学工学部卒業

1994年 4 月 九州大学大学院工学研究科修士課程入学

1996年 3 月 九州大学大学院工学研究科修士課程修了

1996年 4 月＼cjkstart石川島播磨重工業株式会社（現 株式会社 IHI）入社

2003年10月＼cjkstart株式会社アイ・エイチ・アイマリンユナイテッド＼cjkstart転籍 現在に至る

宮田隆司

1944年 1 月 2 日生

1972年 4 月 名古屋大学講師 (工学部)

1974年 4 月 名古屋大学助教授 (工学部)

1974年 6 月 西独 Stuttgart 大学材料研究所 (MPA) 客員研究員

1990年 6 月 名古屋大学教授 (工学部)

1997年 4 月 名古屋大学教授 (大学院工学研究科)

2003年 4 月 名古屋大学評議員

2004年 4 月 名古屋大学大学院工学研究科副研究科長

2006年 4 月 名古屋大学副総長 (産学官連携関係担当)

2008年 4 月 名古屋大学理事 (国際交流 - 産学官連携関係担当) - 副総長

2009年 4 月 名古屋大学理事 (産学官連携・国際学生交流関係担当) - 副総長

現在に至る 


\section{【レーザ圧接された合金化溶融要鉛めつき鋼板と工業用} 純アルミニウム異材接合に関する一連の研究】

「レーザ圧接された合金化溶融亜鉛めっき鋼板と工業用 純アルミニウム異材接合継手の機械的特性」

「レーザ圧接された合金化溶融亜鉛めっき鋼板と工業用 純アルミニウム異材接合部の微細組織観察」

\section{正員 西本浩司君}

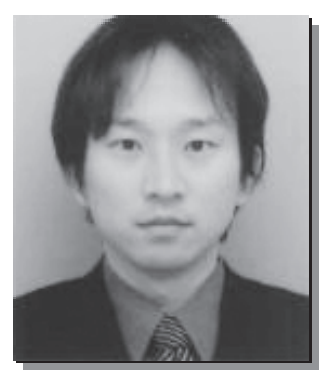

本研究は, 今後自動車の軽量化などで実用的にも重要となるアルミニウムと溶融 亜鉛メッキ鋼板の異材溶接にレーザー圧接の適用を試みたものであり，異材溶接部 のミクロ組織の詳細な観察を通して接合のメカニズムを明らかにするとともに，異 材接合部の機械的特性の評価とあわせて行うことで，実用化に向けた指針を提示し ている、レーザー圧接を用いた異材接合法の今後の可能性を示す優れた成果であり， また異材接合部のミクロ組織解析の詳細さなど研究的にも高く評価できる. 今後の 溶接工学分野におけるますますの活躍と発展を大いに期待するものである.

略歴

昭和 49 年 9 月 15 日生

平成 5 年 4 月 阿南工業高等専門学校文部技官

平成 8 年 3 月 徳島大学工業短期大学部機械工学科卒業

平成15年10月 学士 (工学) の学位取得 独立行政法人大学評価・学位授与機構

平成 21 年 3 月 博士 (工学) の学位取得 大阪大学

平成 21 年 4 月 阿南工業高等専門学校機械工学科助教 現在に至る 


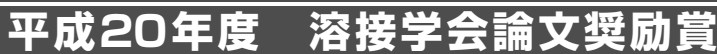

\section{「単結晶合金タービン翼の結晶制御補修に関する研究」を 共通題目とする 4 連報」 （溶接学会論文集第 26 巻第 1 号～第 4 号）}

\section{正員 藤 田善 宏 君}

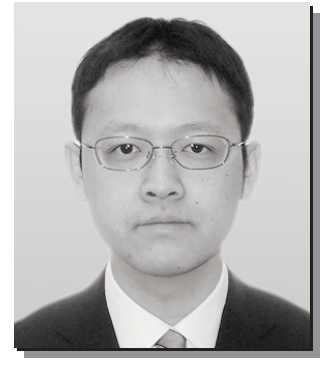

本論文では，単結晶合金タービン翼の補修方法の確立と補修部における結晶制 御 挙動の理解を目的として, 半導体レーザによる溶融・肉盛補修での単結晶化可能補 修条件を組織学的検討ならびに結晶成長に関する理論的検討により明らかとしてい る。レーザによる溶融・肉盛補修の検討では，補修部の組織学的検 討および結晶方 位解析を行い，単結晶化条件を明確化している。また，単結晶 化可能補修領域の拡 大や補修後の後熱処理条件の選定などの検討を行い，本補修法の実施工への適用性 が高いことを示している。また，溶融・肉盛補修部の単結晶化条件を予測すること を目的として, 熱伝導解析, 流体解析, Geometric モデルおよび CET モデルをもと にストレイ結晶形成について解析を行っている。本解析により，低入熱の条件にて 単結晶化が達成されやすいことを示しており，かつ，その妥当性を実験結果との比較により検証し，本解析 の有効性を明らかとしている。さらに, 溶融部の高温機械的特性を評価し, 結晶制御溶融・肉盛により単結 晶合金の肉盛補修が行える可能性を示している。

以上のように，本論文は単結晶合金タービン翼に対する補修方法を確立すべく，実験および理論的解析の 両面から詳細に検討し，単結晶化可能な補修条件および補修部の結晶制御挙動を明らかとし，本補修方法の 適用性ならびに有効性を確認している。これら本論文で得られた知見は, 航空機用ジェットエンジンや発電 用プラントで用いられるタービン翼などの単結晶構造物の補修に対して重要な示唆を与えることが展望され, その成果は, 学術的・工業的に寄与するところが大である.

\section{略歴}

1978年 6 月 22 日生

2002年 3 月 大阪大学工学部応用理工学科卒業

2007年11月 大阪大学大学院工学研究科生産科学専攻博士後期課程修了

2007年12月（株）東芝電力システム社入社京浜事業所溶接センター配属 現在に至る 


\section{田中鲌久人賁}

\section{溶接電源融合型高性能アーク溶接 ロボットシステムの開発}

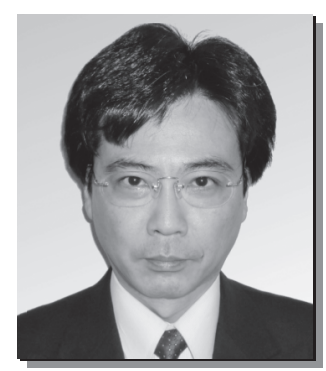

向井康士君

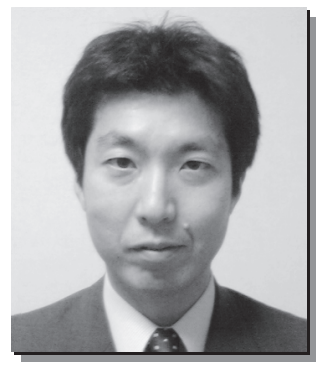

相 見 圭 君

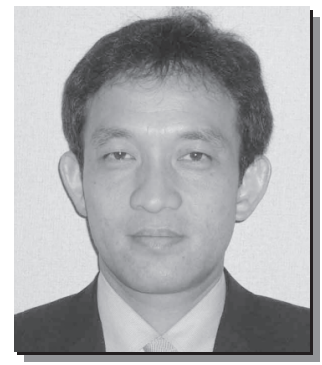

川本 篤 寛 君

\section{向井康士君 \\ 相見圭君}

地球環境保護の観点から自動車及び二輪業界では燃費向上を目的とした軽量化の ために, 年々薄板化が進められている。このため, 薄板のロボットによるアーク溶 接においては, 生産性の向上, 溶接品質の向上が期待されており, 溶接速度の高速 化とスパッタの低減, 溶落ちゃアンダーカットなどの欠陥防止と言う, 相反する課 題の解決が求められている.

そこで受賞者らは,「高速溶接性」と「条件裕度の広さ」を実現するために, ロボ ットと溶接機との境界を無くし, 融合化した制御装置によってアーク溶接に特化し た専用ロボットの動作制御と溶接波形制御を一元的に制御するアーク溶接専用ロボ ットを開発した。

このアーク溶接専用ロボットは, 従来の半自動溶接機をベースとしたロボット用 溶接電源とは一線を画すロボット専用の溶接電源を備え, クラス最速の超高速イン バータ $(100 \mathrm{kHz})$ の開発により実現したフルソフトウェア制御による溶接波形制御 技術の確立が最も大きな特徴である.

これまでハードウエアの特性に縛られていた制約を排除するリアクタレス制御に より，様々なパラメータを自由に切り替えて短絡溶接とパルス溶接といったそれぞ れの溶接法に最適な特性をソフトウエア制御で創り出し, 適応範囲を大幅に広げる ことが可能となった.

高速溶接を行うためには短絡周期の安定化と短周期化が必要となり, 短絡移行領 域では短絡溶接とパルス溶接の長所を併せ持った低スパッタ（二次 SW 制御）の溶接 法として新短絡波形制御を開発し，溶接速度 $1.0 \mathrm{~m} / \mathrm{min}$ の時にスパッタ発生量を $1 / 5$ 〜 1/7 に低減し，ギャップに対する条件裕度も大幅に広げることができた.さらに， グロビュール移行領域ではパルス毎に短絡させて溶滴を移行させる 1 パルス $1 \operatorname{dip} の$ 短絡移行の溶接法として新パルス波形制御を開発し, 溶接速度 $1.5 \sim 2.0 \mathrm{~m} / \mathrm{min}$ の高 速溶接を可能とし, 溶落ちやアンダーカットの発生を抑制しギャップに対する条件 裕度も大幅に広げることができた。

このアーク溶接専用ロボットは, 溶接制御ソフトのバージョンアップにより最新 の溶接ソリューションが利用でき, ソフトと周辺機器を切り替えることでアルミ MIG や TIG への用途展開も容易である.

以上の様に, 新開発のアーク溶接専用ロボットは「溶接生産性と溶接品質」の大 幅な向上を実現するばかりでなく，フルソフトウェア制御技術の確立により「革新 性と拡張性」を飛躍的に向上させた点で溶接学会及び溶接業界全般におけるロボッ ト溶接の進化に大きく貢献するものである. 
向井康士

1961年 4 月 26 日生

1986年 3 月 長岡技術科学大学大学院工学研究科修士課程終了

1986年 4 月 松下電器産業(株) (現在 パナソニック(株) 入社産業機器研究所配属

1996年 4 月 松下産業機器(株) (現在 パナソニック溶接システム株) 溶接システム事業部ロボッ 卜部技術課主任技師

2007年 6 月 松下溶接システム(株) (現在 パナソニック溶接システム株) 技術グループグループ マネージャー

2008年11月パナソニック溶接システム株取締役 CTO 技術グループグループマネージャー 現在に至る

相 見 圭

1965年12月29日 生

1991年 3 月 同志社大学大学院工学研究科博士課程前期修了

1991年 4 月 松下電器産業(株) (現在 パナソニック株) 入社 松下産業機器(株産業機器研究所配 属

2001年10月＼cjkstart松下溶接システム株）(現在パナソニック溶接システム(株) 技術グループ転属

2007年 6 月 同 技術グループ機器開発チーム チームリーダ 現在に至る

川 本 篤 寛

1967年 1 月 28 日生

1989年 3 月 大阪大学工学部治金工学科卒業

1991年 1 月＼cjkstart松下電器産業(株) (現在パナソニック(株) 入社

松下産業機器株）（現在パナソニック溶接システム(株）溶接機事業部配属

2006年 4 月 松下溶接システム株) (現在 パナソニック溶接システム(株) 技術グループチーム リーダ

現在に至る 


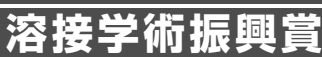

溶接学術振興賞は, 平成元年 9 月に創設され, 各支部において, 溶接・接合に関し, 学術研究及び教育活 動により学術・技術の振興, 進歩発展に著しく貢献した方に対し, 支部長の推薦に基づいて審査し, 学会長 から贈られます。

\section{東北支部}

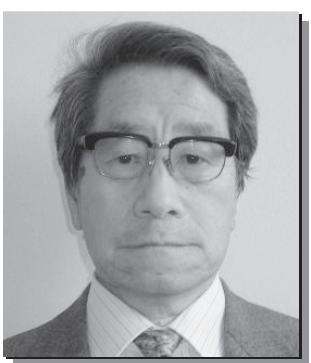

青 嶋 勇 氏

昭和14年 2 月 7 生

元 宮城県工業技術センタ

一 副所長
青嶋勇氏は，永年にわたり溶接学・協会の活動に参画し，その運営と溶接関連業 界の発展に大きく貢献してきた。特に, 溶接学会東北支部においては商議員, 役 員として 30 年に亘り活躍し, 特に平成 4 年から平成 12 年の 8 年間 (社) 溶接学会 東北支部の支部長および副支部長として, 東北六県産学官連携の場である接合研 究会を主宰, 研究活動の基盤を築くとともに, とりわけ公的試験研究機関の溶 接・接合に関する技術交流を図るなど関連業界の技術振興に著しく貢献した。

主な研究実績としては，下記のようなものがある.

1.アルミニウム溶接金属の窒素含量および気孔 (昭和 $44 \sim 45$ 年度)

2. アルミニウムの $\mathrm{Ar}-\mathrm{N} 2$ ガス・メタルアーク溶接 (昭和 $44 \sim 45$ 年度)

3. 半自動溶接の適用に関する研究 (昭和 46 年度) $※ \mathrm{~T}$ 継手の半自動溶接（特許 取得)

4. 厚肉鋳物の狭開先溶接に関する研究（昭和 48 年度）

5. 厚鋼板の消耗ノズル式エレクトロスラグ溶接 (昭和 49 年度)

6. オーステナイト系ステンレスクラッド鋼の溶接 (昭和 56 年度)

7. 抵抗溶接の強度特性に関する研究 (昭和 58 年度)

8. 耐候性鋼の溶接性に関する研究 (昭和 60 年度)

9. $\mathrm{Ni}-\mathrm{Ti}$ 形状記憶合金の溶接・接合に関する研究 (昭和 62 年度)

10. 超音波による鋳鉄品の材質評価システム開発（昭和 63 年度)

11. X 線透過試験法及び超音波映像法による新素材の欠陥検出 (平成 2 年度)

これらの貢献により，溶接学会から平成 2 年度溶接技術奨励賞が授与された.

また，同氏は，(社）日本溶接協会東北地区溶接技術検定委員会幹事，副委員長，全国溶接競技大会審査委員 並びに全国鉄構工業協同組合の工場認定評価員などを長年にわたり歴任している。

以上により，溶接・接合に関する学術振興及び技術的支援活動は極めて顕著であり，技術向上と普及に努 めた功績は極めて大きい.

昭和 37 年 3 月 岩手大学工学部金属工学科卒業

昭和 37 年 4 月 東北大学工学部金属材料工学科文部教官助手

昭和45年10月＼cjkstart宮城県工業技術センター割愛

昭和62年 4 月 宮城県工業技術センター開発部長

平成 3 年 4 月 宮城県工業技術センター指導部長

平成 4 年 4 月 宮城県工業技術センター副所長，溶接学会東北支部副支部長 ( 平成 8 年 3 月)

平成 8 年 4 月 溶接学会東北支部支部長 ( 平成 12 年 3 月)

平成 9 年 4 月 宮城県工業技術センター技術参事兼副所長

平成11年 3 月 宮城県工業技術センター定年退職

平成11年10月 社団法人日本溶接協会東北地区検定委員会主任

平成 20 年 3 月 社団法人日本溶接協会東北地区検定委員会定年退職 


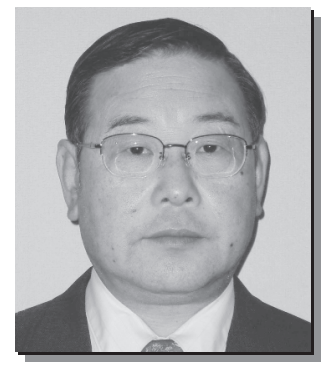

三田常夫 氏 昭和23年 7 月 11 日生 ダイヘン溶接メカトロシス テム（株）理事
三田常夫君は 1975 年に日立精工(株)〔現日立ビアメカニクス(株) 入社後, 現在に 至るまで, アーク溶接機器分野において, $\mathrm{TIG}$ 溶接および $\mathrm{CO}_{2} \cdot \mathrm{MAG} \cdot \mathrm{MIG}$ 溶 接を主対象とした溶接現象の制御方法の研究開発に一貫して取組み, その成果を 実現する新しい溶接電源を先駆的に市場に発表し, 我が国溶接電源開発のリーダ 一として活躍してきており，溶接技術の学術研究ならびに教育活動により学術・ 技術の振興，進歩発展に大いなる貢献を果たしてきた。その主な内容は次のよう である。

（1）インバー夕制御溶接電源の開発とその普及拡大

制御周波数 $20 \mathrm{kHz}$ のインバータ制御ティグ溶接機を開発し，その高速・精密な 出力制御特性を明らかにするとともに，その特性を活用した新しい溶接電源を 次々に開発・実用化し，溶接技術の発展に大きく貢献した。

(2) $\mathrm{CO}_{2}$ アーク溶接の電流/電圧波形解析とその応用

$\mathrm{CO}_{2}$ アーク溶接の電流/電圧波形解析から，溶接作業性は短絡時間とアーク時間 の標準偏差に大きく依存することを見出し，適正電圧を自動設定するファジィ制御溶接機を商品化し，非熟 練作業者の負担軽減に寄与した。

(3) マイコン波形制御溶接電源による $\mathrm{CO}_{2}$ アーク溶接のスパッタ低減

出力電流・電圧を任意に制御できるマイコン制御の溶接電源を開発し，スパッタ発生に大きく関係する波 形パラメータを明らかにするとともに，スパッタを大幅に低減する出力制御方法を開発した.

(4) 定電圧特性パルスマグ・ミグ溶接電源の開発とその知能化

特別なアーク長制御を必要としない定電圧特性のパルスマグ・ミグ溶接電源を開発するとともに，低周波 パルス周期の整数化・適正電圧の自動設定などの高機能化を図り，自動車部品溶接への適用を拡大した.

（5）低周波交流マグ溶接電源の開発と極薄板溶接への適用

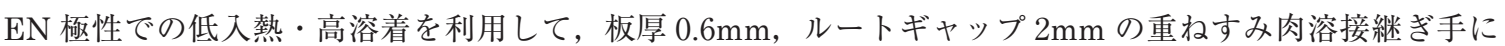
おいても穴あき・溶落ちを生じない低周波交流マグ溶接電源を開発し，自動車ボディの生産性向上に大きく 貢献した.

（6）アルミニウム溶接における新交流波形制御技術の開発

交流ティグ溶接の交流周波数を増加させることによってアークの集中性が改善できること，交流周期と直 流周期を低周波で切り替える交流/直流複合パルスミグ溶接で溶込み・ビード形状を任意に制御できること，な どを見出し，アルミニウム溶接の作業性改善を図った。

その他, 高速 $\mathrm{CO}_{2}$ アーク溶接電源, 矩形波パルス溶接電源, 小電流パルスミグ溶接電源, 大電流パルスマ グ溶接電源，などのユニークな溶接電源の開発・実用化も行っている.

また溶接学会においては，溶接法研究委員会副委員長，溶接アーク物理研究委員会幹事，軽構造接合加工 研究委員会委員，東部支部支部長，教育委員会委員，溶接協会においては溶接管理技術者評価委員会委員， 溶接管理技術者再認証委員会委員，溶接協会神奈川県支部理事などの役割を果たすとともに，溶接学会溶接 基礎講座，溶接協会溶接管理技術者講習会，各種機関·団体の講習会など多数の講習会・講演会の講師とし て，この技術分野における教育・指導的立場から積極的な活動を展開しており，その業績は広範囲な産業分 野で認められている。

\section{略歴}

1972年 3 月 大阪大学工学部 溶接工学科 卒業

1972年 4 月 (株)宮地鐵工所 入社

1975年 3 月 同社 退社

1975年 6 月 日立精工(株〔現日立ビアメカニクス(株)〕 入社

1991年12月 大阪大学 博士（工学）

2002年 4 月＼cjkstart同社＼cjkstart溶接機本部 副技師長

2005年 7 月＼cjkstart業務移管に伴い日立ビアエンジニアリング株にに転籍 同社 設計部 副技師長

2005年12月 同社 退社

2006年 1 月 ダイヘン溶接メカトロシステム株) 入社 同社理事 現在に至る 


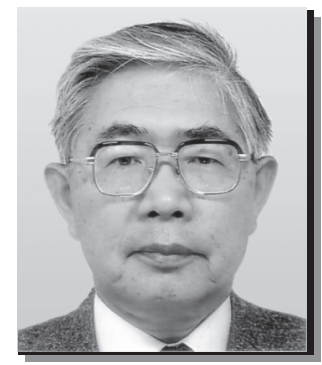

沓名 宗 春 氏 昭和 20 年 1 月 3 日生 (株)最新レーザ技術研究セン ター代表取締役
沓名宗春君は, 名古屋大学卒業後, 40 余年の長期に涉り, 一貫して溶接工学と レーザ加工工学に関する研究に携わり, 接合技術分野の発展に多大に貢献してき た. 同君の研究成果は多岐に渉るが，大掴みにとらえると，大学院時代のステン レス鋼の熱間割れに関する研究，川崎重工業時代の大出力電子ビーム溶接に関す る研究および名古屋大学教員時代のレーザ加工に関する研究である.オーステナ イト系ステンレス鋼の凝固時のフェライト晶出が熱間割れの抑制に対して重要な 役割を果たしていることを指摘した研究は, その後の治金的研究の端緒となる成 果である。川崎重工業では大出力の電子ビームを利用し， $100 \mathrm{~mm}$ を越える極厚鋼 板を一層溶接する技術を実用化した。アーク溶接などの従来法では困難な深溶込 み溶接法の確立は溶接設計法自体にも影響を与える重要な成果である. 名古屋大 学の教員となってからはレーザ溶接, レーザフォーミング, レーザロール溶接, 特殊レーザピーニングなど新レーザ加工法の研究開発に邁進し, 数多くの国際会 議に研究発表, 招待講演を行った。 研究活動に並行して, 中部レーザ応用技術研 究会を立ち上げて産学のレーザ加工研究者の交流の活性化に尽力するとともに,「最新レーザ利用生産システ ムおよび高強度高機能部材の開発」や「特殊レーザピーニング技術の開発」など産官学連携による技術の発 展に貢献した。

26 年の間, 同君は大学教員として多くの溶接技術者を養成したばかりでなく, JICA 教育・訓練委員長と して JICA 溶接技術者研修コースの実施に尽力し，300名以上の海外溶接技術者の育成に精勤した。養成され た技術者は国際化の流れの中にある日本の溶接産業界にとって貴重な人的財産となっており, 溶接工学の教 育者として同君の果たした役割は非常に大きい.また名古屋大学赴任以来, 同君は溶接学会の研究会, 委員 会に幹事および委員長として活動し, 特に支部の常任幹事および支部長として四半世紀の長期に涉り, 学会 の活性化に尽力した。

\section{略歴}

昭和 47 年 3 月 名古屋大学大学院工学研究科博士課程金属工学及び鉄鋼工学専攻 満了 昭和 47 年 4 月 川崎重工業株式会社入社 昭和 57 年 3 月 川崎重工業株式会社退社 昭和 57 年 4 月 名古屋大学工学部助手 昭和60年 4 月 名古屋大学工学部講師 平成 4 年 4 月 名古屋大学工学部助教授 平成18年 4 月 名古屋大学大学院工学研究科マテリアル理工学専攻教授 平成 20 年 4 月 光産業創成大学院大学特任教授 (株)最新レーザ技術研究センター代表取締役 現在に至る 




瀬 川 雅 司 氏 昭和 22 年 11 月 22 日生 川崎重工業(株)車両カンパニ 一常務取締役
瀬川雅司君は，昭和 45 年大阪大学工学部造船学科を卒業後，川崎重工業(株)に 入社，神戸造船工場に配属され，二十有余年に亘り，造船における溶接技術を始 めとする生産技術全般について, 研究開発ならびにその実用化を行ってきた。ま た，平成 10 年には同社車両事業部に異動し，その生産部門の統括を行い，現在で は，車両ビジネス全般を統括している。

同君の業績は，次のとおりである.

（1）造船分野では，セミメンブレン方式 LPG 船や潜水船等の高付加価值船舶につ いて，溶接部の健全性，強度ならびに破壊じん性に関する高い要求を満足す る種々の大入熱施工法およびアーク現象をモニタニングし，その変動に対す る適応制御機能を具備した専用溶接装置や沉用多関節ロボットシステムの開 発実用化を行うとともに，それを支える生産システムについて，「生産の流れ 化」および「自動化」を基本思想とした抜本的な改革を行い，当該船船の溶 接継手の信頼性および生産性向上に大きく寄与した。その成果によって「防 衛装備協会賞」等を受賞し, 高い評価を得ている.

(2) 高速車両分野では，その空気抵抗を最小化するための複雑な 3 次元曲げ曲面を有する先頭構体の施工技 術の確立およびアルミニウム合金製薄板の中空大型押出し形材に対する GMAW 自動溶接法を開発し, その高速化および軽量化を達成し，N700 系新幹線等の新世代新幹線の実用化に多大な貢献を行った.

（3）これら日本固有の施工技術をベースとして開発された $700 \mathrm{~T}$ 型新幹線車両を台湾新幹線プロジェクトに投 入し，これを成功裏に完遂するとともに，中国新幹線プロジェクトでは，その技術移転に大きく貢献し， 両国政府から高い評価を受けている。

(4) 加えて，アルミニウム合金製構体に対する摩擦攪拌接合ならびに摩擦点接合の適用および ステンレス製 構体に対する世界初のレーザ溶接法の適用等，新接合法を積極的に車両構体に適用し，その信頼性なら びに生産性向上に大きく貢献した.

さらに，同君は，溶接学会関西支部長，日本溶接協会兵庫県支部長ならびに日本鉄道車輌工業会理事 等を 歴任し, 溶接学会・日本溶接協会の各種活動においても指導的な役割を果たすなど, 我国溶接界の発展に大 きく寄与してきた。 


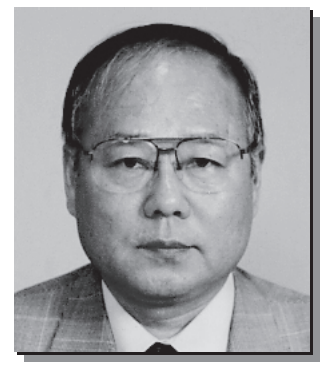

奥 本 泰 久 氏 昭和16年12月19日生 近畿大学工学部 特任教授
奥本泰久君は昭和 40 年広島大学工学部船舶工学科を卒業後, 石川島播磨重工業 (株)（IHI）に入社し, 相生工場にて船殼構造の詳細設計やシステム開発を, 次い で東京本社で船舶・海洋構造物の基本設計, 構造解析, CAE システム開発に従事 した。昭和 61 年から 3 年間いすぶ自動車(株で CAE に従事した後, IHI に復帰し 生産技術部門のリーダーとして造船工場の近代化に貢献した。

平成 4 年に近畿大学工学部機械システム工学科に着任し, 助教授を経て教授に 昇格, 同時に大学院前期・後期過程および工業技術研究所の教授を併任した. 学 部教育では材料力学や機械設計の講義を, 卒業研究や修士論文では溶接や構造分 野で CAE を中心とした研究指導を行った。この間, 造船・溶接系の工学博士 3 名 の指導に当たった。また，造船現場での体験を元に，産業界への技術指導に熱心 に取り組んでおり，溶接技術の研究開発および教育に大きく貢献してきた.

同君の主な研究業績については, (1)溶接熱変形, 残留応力, 歪取りの数值シミ ユレーション，(2)熱切断や線状加熱曲げの数值解析，(3)高精度生産システム（単板スリット工法）の確立，(4) FCB や超厚板, アルミタンクの溶接品質の向上, 5)溶接の作業性評価（ディジタルヒューマン, 感性工学, 生体工学を応用)，(6AI 手法を用いた溶接作業の最適化，など幅広い分野で先駆的な研究を実施してきた。す なわち狭義の溶接工学よりも, 溶接・組立てを一つのシステムとして捉え, 広く異分野技術を取り入れ. 多 面的に研究したことは高く評価されている.

一方，同君は溶接学会では代議員（平成 18～19 年)，中国支部商議員 (平成 12 年〜現在)，副支部長 (平成 16 年〜現在）を歴任し，溶接技術の進歩・普及に大きく貢献している. 特に, 支部活動の中心である「溶 接・接合学修会」や各種の研究会, 講演会では中心となって企画・運営に携わり, 中国地域の特徴である「も の作り」の技術力向上に大きく貢献している。他方，国際的な活動も活発で，IIW 関連の各種国際会議で多 くの研究発表を行っている.

以上のように奥本泰久君が溶接の学術振興に貢献した功績は誠に顕著といえる. 


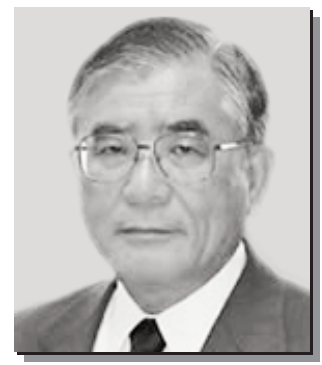

屋 良 秀 夫 氏 昭和15年9月11日生 沖縄職業能力開発大学校 校長

屋良秀夫君は昭和 39 年琉球大学機械工学科を卒業後, 昭和 44 年 4 月に中部工 業高等学校教諭, 昭和 47 年 5 月に琉球大学理工学部助手, 昭和 59 年 10 月に琉球 大学短期大学部講師, 昭和 61 年 4 月に琉球大学短期大学部助教授, 平成 2 年 10 月に琉球大学工学部教授, 平成 18 年 3 月定年により退職後, 沖縄職業能力開発大 学校の校長に就任され, 現在に至っている.

この間，同君は，学術研究の面において，スガウェザリング技術振興財団特別 技術功労賞 (1995, 国内), Best Paper Award of the 20th ASME Informational Composite Materials Symposium（1998，国外), ASME International Petroleum Division, Material Committee. Composite Materials Symposium Paper Award （1999，国外）を受賞している.

研究テーマは，水中溶接に関する研究，高クロム系 2 相ステンレス鋼溶接棒に よる湿式水中溶接部の溶接割れ防止に関する研究, 溶射による傾斜機能皮膜の作

製，鋳込み法による複合材料の接合特性，腐食環境下におけるコーティング材の 疲労特性，放電プラズマ焼結法による溶射皮膜の改質，放電プラズマ焼結法（SPS）による固体接合，石炭灰 から有価物の抽出方法, 微生物誘起腐食の防食法, 家畜液状排泄物適性処理プラントの開発, 固粒化剤によ る污泥等の処理法と多岐にわたっている。また，湿式水中溶接における TRC 試験，湿式水中アーク溶接に関 する研究，フレーム容射に関する研究，部分溶射皮膜材の腐食環境下における疲労特性，塗布式粗面形成法 による溶射皮膜の特性など溶射皮膜摩耗特性に関する研究などの研究業績を残している．また，平成 11 年度 溶接学会秋季全国大会の沖縄開催に際し，実行委員会副委員長として尽力された。

このように溶接・接合の分野において大きな成果を挙げ，溶接学術の発展に貢献したところ大である。

さらに，同君は九州支部商議員・幹事を歴任し学会の運営にも貢献すると共に，沖縄の溶接・溶射事情， 沖縄県における溶射の現状, 沖縄における腐食防食の現状など地域性に根ざしたフィールドワークや, (財) 日 本ウエザリングテストセンター会長，(社) 日本防錆技術協会沖縄支部長，(社) 日本溶接協会沖縄県支部長， 異業種交流間で結成している「津梁ネットワーク」会長などの立場を通して，地域における溶接技術の普及， 啓蒙に努め，溶接技術の振興にも大きく貢献した。

以上のように，屋良秀夫君は溶接・接合に関する学術及び教育そして溶接技術の地域振興に寄与した功績 は誠に顕著である。

\section{略歴}

昭和39年 3 月 琉球大学機械工学科卒業

昭和 44 年 4 月 中部工業高等学校教諭

昭和 47 年 5 月 琉球大学理工学部助手

昭和59年10月＼cjkstart琉球大学短期大学部講師

昭和61年 4 月 琉球大学短期大学部助教授

平成 2 年 10 月 琉球大学工学部教授

平成18年 3 月 定年により退職

平成18年 4 月 沖縄職業能力開発大学校校長 現在に至る 


\section{原子力関連機器ならびに真空機器の製造への} ビーム応用とアーク溶接プロセス技術の開発

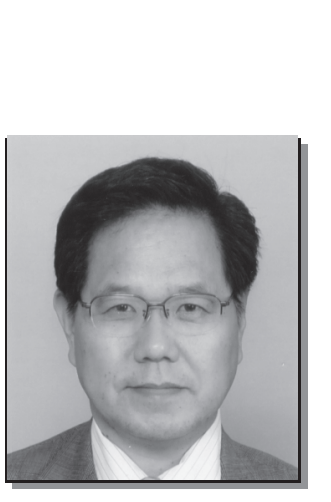

北 側 彰 - 氏

\section{正 員 北 側 彰 一 君}

北側彰一君は原子力関連機器ならびに真空機器の製造で必要とされるレーザ溶接 技術、電子ビーム溶接技術ならびにアーク溶接技術に扔いて，広範な溶接技術開発な らびにその応用に尽力しこれらの生産分野で多大な貢献が認められる．以下に業績 を要約する。

1）電子ビーム溶接技術の応用に関する貢献

ア）電子ビームによる超高真空用材料の開発「超高真空用金属材料の表面改質とそ の評価」においては, 電子ビーム溶接を用いた表面改質により, 高真空中でステンレ 又鋼から放出される主成分の $\mathrm{H} 2$ 抢よび $\mathrm{H} 20$ が一般的に用いられる超高真空用材料 より桁違いに少ない超高真空用・極真空用材料の開発を成功させた.

イ）電子ビーム溶接による半導体プロセス用真空容器の製造切削で製作されてい たアルミニウム合金製真空容器の製造に電子ビーム溶接を採用し超高真空容器の製 造に成功したことは, 昨今の大型真空容器製造への電子ビーム溶接の端緒を築いた。

2) 真空機器への $\mathrm{CO}_{2}$ レーザ溶接の応用に関する貢献

レーザ溶接変形の定量化と高精度大型真空容器の製作「304 ステンレス鋼のレーザ溶接変形に関する研究」で は, レーザ溶接変形の基礎的事項（角変形，縦曲り変形）を検討し，溶接後のひずみ矯正ができない製品の製 造で重要となる溶接手順や溶接時期に関する数值的指針を求めている. また,「レーザ溶接による 304 ステン レス鋼製容器の製造に関する研究」では, ステンレス鋼の物性, 入熱, 寸法, 形状, 溶接位置などとたわみ量 の関係（最大たわみ式の導出）などにより，4700 mm と非常に長く、断面形状が複雑なステンレス鋼製容器（高 輝度放射光発生装置) を最大変形量 $0.5 \mathrm{~mm}$ 以内の精度で製造したことが報告されている。レーザ溶接変形挙 動を定量化し, 矯正なしに高精度大型構造物を製造できることを実証したことは生産技術の向上に大きく貢 献している.

3）原子力関連機器への YAG レーザ溶接の応用に関する貢献

リアルタイムシームトラキングレーザ溶接装置の開発と実用

「ステンレス鋼製薄板複層容器のレーザ溶接」では, 長さ $3 \mathrm{~m}$ のコの字型プレス成型ステンレス材 (板厚が $1.2 \mathrm{~mm}$ ） 2 つ突合せたチューブの溶接およびその外周 4 面に板厚が $0.5 \mathrm{~mm}$ の材料をすみ肉溶接した薄板複 層容器を製造するため, 国内で始めてリアルタイムシームトラッキングセンサを登載したレーザ溶接システ ムを開発し実用化した。突合せ溶接時の角変形による焦点位置ズレやすみ肉溶接時の目はずれ防止を,リア ルタイムシームトラッキング技術で克服できることを実証し, 累計 3000 体以上の製造で害用されたことは海 外にも認められている (NAC F ab edge Aug-2004). 上記の新しいレーザ溶接プロセスの開発は, 生産技術 の向上に大きく貢献している.

4) 原子力関連機器 (キャスク)へのアーク溶接の応用に関する貢献

ア）銅フィン溶接装置の開発と実用

原子力関連機器においては 2 重円筒容器の間に電熱特性を確保するため銅製のフィンを溶接する必要があ る.これは銅と炭素鋼の異材溶接であり, 狙い位置を間違えると微細な割れを発生するため精度の高い倣い ローラを開発し, 仮付けと本溶接を安定に実施できるよう電源特性を調整した溶接装置を開発した. 本装置 は 1992 年に開発し現在も引き続き使用している.

イ）自動線栓溶接機の開発と実用

核燃料を搬送するキャスクに用いられるバスケットの収納筒の取付け方法および装置（小形自動栓溶接装 置）も開発し実用化している。 バスケットは $150 \mathrm{~mm}$ 角, 長さが $4000 \mathrm{~mm}$ 程度のステンレス鋼製収納筒をス テンレス鋼製の栈部材を介して溶接された構造体である。本装置により，狭い空間で収納筒と栈部材界面の 溶込み面積を増大し, 同時に余盛の平滑化を達成している.この装置は平成 10 年よりキャスクのバスケット 収納筒の取付けに適用され，45000 点以上の施工実積を有している.

長尺・狭價部での特殊溶接装置の開発は生産技術の向上に大きく貢献している.

5）その他

大出力 $\mathrm{CO}_{2}$ レーザによる新型道路橋用床板製造に関する研究では, 世界最大の試作サンドイッチパネルの 
製作に成功し，重構造物へのレーザ重ね溶接の可能性を提案し，生産技術の向上に貢献している. 学協会においては，溶接学会溶接法研究委員会幹事を務め，学会活動も活発である.

\section{略歴}

1980年 3 月 25 日 大阪大学工学部溶接工学科卒業

1982年 3 月 25 日 大阪大学大学院工学研究科溶接工学専攻博士前期課程修了

1982年 4 月 1 日 日立造船株式会社 入社 溶接・塗装研究室配属

1995年 5 月 1 日 株式会社日立造船技術研究所主任研究員

1998年 8 月 1 日 日立造船株式会社技術研究所主管研究員

2002年 3 月 25 日 工学博士 (大阪大学)

2005年 8 月 1 日 日立造船株式会社＼cjkstart事業・製品開発センター技術研究所主席研究員 現在に至る 


\section{溶㩲学会ベストオーサー賞}

溶接学会ベストオーサー賞は, 平成 15 年に創設され, 会誌「溶接学会誌」に発表された記事のうち, 特に

多数の会員の研鑽，及び，学術，技術の向上，普及に貢献した記事の著書に授与されます.

（1）内原正人君 住友金属工業(侏)

第 77 巻 8 号 総合企画担当記事 レビュー\&トレンド「自動車用薄鋼板の高能率溶接技術」

溶融溶接のトレンドである自動車向け薄鋼板の溶接技術に関して, 自動車用鋼板の現状から，抵抗又 ポット溶接, アーク溶接, レーザ溶接に亘るプロセス技術の最新動向まで, 豊富で貴重な図表を使って 解りやすく纏めて解説している。レビュー\&トレンドという記事に相応しい内容である.

（2）森清和君，樽井大志君，長谷川隆久君，吉川暢弘君白産自動車(侏)

第 77 巻 3 号 プロセス企画担当記事 特集 自動車産業におけるリモート溶接の実用化

「自動車ボディへのリモート溶接技術の適用」

自動車産業に㧍ける最先端のロボットリモートレーザ溶接の実用事例を紹介され，生産ラインへの新 技術導入に際して特に重要な品質モニタリング技術についても新しい概念の手法について判り易く解説 いただいている.ささら，今後の課題についても明確にまとめていただいた。この分野の専門家のみな らず，溶接学会会員にとってきわめて有用な内容と判断できる.

（3）児島明彦君新日本製鐵株

材料企画担当記事 溶接接合教室-基礎を学ぶ- 「第 2 章 金属材料と溶接性 $2-1$ 「鋼の製造と性質」」 本記事では，鋼の製造法と性質に関して，最新の知見も踏まえながら，各工程の製造技術，製品の特 性について，わかりやすく記述されている，鉄鋼生産分野の専門家のみならず，溶接学会会員にとって きわめて有用な内容である. 


\section{演接学会技術貢塥裳}

溶接学会技術貢献賞は，平成 19 年度に創設され，溶接技術の開発または応用普及に中核的な役割を果たし，そ の業績顕著な方及び溶接技術について若手技術者への教育・指導・育成の業績顕著な方に贈られます。

\section{自動車用鋼板の溶接技術の開発・実用化への貢献}

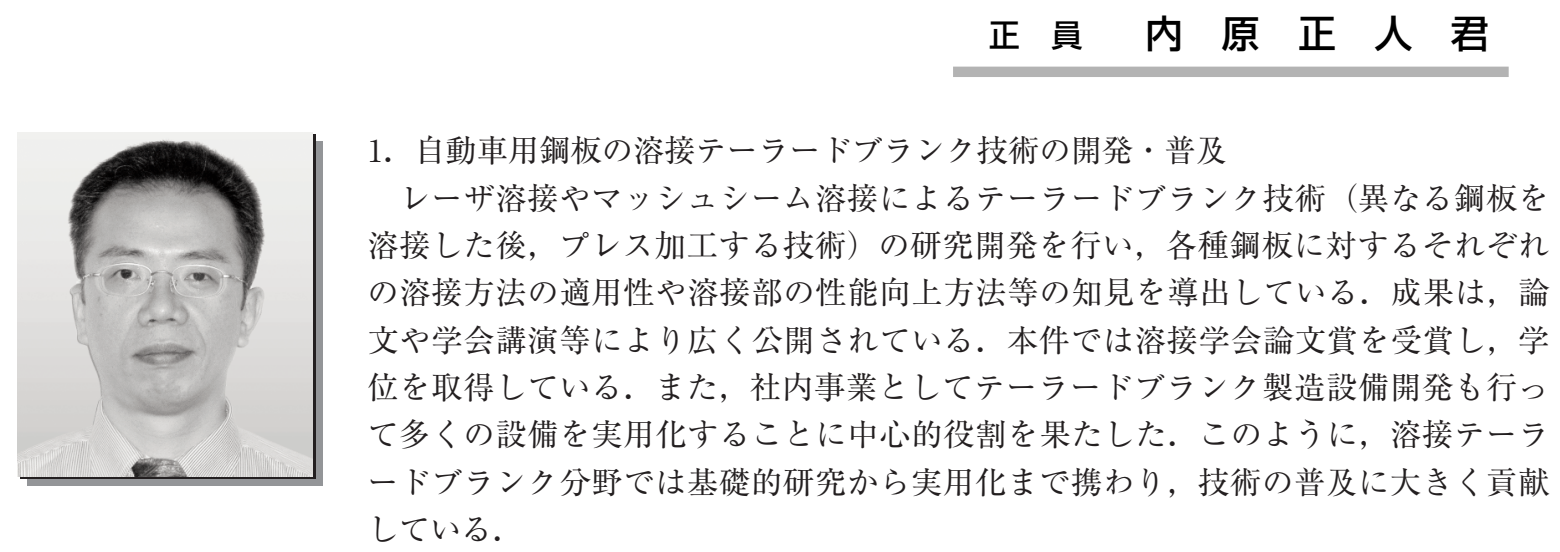

2. 自動車用鋼板のアーク溶接技術およびレーザ・アークハイブリッド溶接技術の開発

アーク溶接関連で自動車業界のニーズに対応した多くの開発を行っている，パルスマグ溶接用シールドガ スの開発，薄板すみ肉溶接継手の度労強度の研究，溶接部の塗装性向上に関する研究がその事例である。ま た，将来溶接技術として，レーザ・アークハイブリッド溶接技術の研究を行い，高張力薄鋼板の継手で高い 信頼性が得られることや，高速溶接が可能なことから，自動車分野で高い可能性を有することを導き出して いる.

3. 若手研究者の指導, 育成

社内では，若手研究者を指導し研究開発を推進している，公表事例として，スポット溶接継手はく離強度 に関する研究，片側スポット溶接技術の開発，微細粒鋼の自動車用鋼板としての性能に関する研究がある.

4. 自動車業界における溶接技術開発および普及への貢献

自動車および関連メーカと多くの共同開発を推進し，自動車メーカにおける技術開発に重要な役割を果た している．例えば，通電制御によるスポット溶接のチリ発生抑制技術の実用化や，突き合わせマッシュシー 厶溶接技術の開発が公表されている。また，多くの技術解説資料執筆や講演会の講師として，自動車業界の 溶接技術者の技術力向上に貢献している。一方で，自動車製造現場にも足を運び，溶接技術協力を通じ，表 面処理鋼板や高張力鋼板の普及に寄与し，自動車産業発展の一翼を担っている.

略歴

1964年10月23日生

1987年 3 月 大阪大学工学部 溶接工学科卒業

1989年 3 月 大阪大学大学院 博士前期課程溶接工学専攻修了

1989年 4 月 住友金属工業株式会社入社 以来 総合技術研究所にて主に自動車用鋼板の溶接接 合分野の研究開発に従事，現在に至る

2006年 3 月 学位 (博士 (工学), 大阪大学) 取得 


\section{進化する厚鋼板の溶接技術・溶接材料の 開発に対する技術貢献}

\section{正員早川直哉 君}

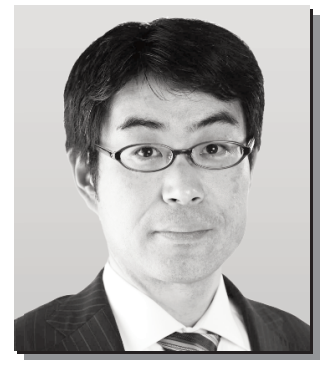

早川直哉君は 1991 年 3 月東北大学大学院工学研究科材料加工学専攻を終了後, 川崎製 鉄（現 JFE スチール株式会社）に入社，研究開発部門に配属となる．極厚ボックス柱の 高能率溶接技術の開発，㧍よび高能率サブマージアーク溶接材料の開発を行い，板厚 $80 \mathrm{~mm}$ 鋼板の 1 ラン溶接技術や，大入熱での高能率マルチパス溶接技術，また, $590 \mathrm{~N} / \mathrm{mm}^{2}$ 級ビルト H の組み立て溶接技術などを開発し，主に建築用途に適用される厚鋼板の高能 率溶接技術の発展に貢献した。 その後, 独立行政法人物質材料研究機構に特別研究員と して赴任し，「超鉄鋼プロジェクト」に参画．軟鋼組成で 80 キロの強度を目指す超鉄鋼 の溶接熱影響部特性を研究し, 80 キ口超鉄鋼の開発に貢献するとともに, 高強度鋼の継 手疲労強度・耐低温割れ性を改善する低変態温度溶接材料の開発に参画し，溶接金属の 基礎的特性を明らかにするとともに高強度鋼で課題となる継手疲労強度と低温割れを克服する溶接材料の開発に貢 献した。 その後, 再び同社の研究開発部門に復職する。 それからは, 主としてラインパイプ用厚鋼板の溶接技術に 関する研究開発に従事し, API-5L X65 以上の高強度 UOE 鋼管のサブマージアーク溶接材料掞よび溶接技術の開発 を遂行する。

同君が開発に携った代表的なものとして，建築用厚鋼板の高能率 (大入熱) 溶接技術の開発や高強度鋼の適用を 見据えた低変態温度溶接材料の開発がある。

高層化・大スパン化の社会的ニーズにより極厚化したボックス柱の製造コスト合理化要求にこたえるべく，ボッ クス柱の高能率溶接技術開発に取り組み，高勒性の鉄粉添加フラックスを開発，これを活用した大入熱 1 ラン溶接 技術を開発した。さらにファブリケーターの設備制約にあわせ，溶接フラックス添加元素と溶接積層の最適化によ り極力パス数を抑えた大入熱多層溶接技術を開発した。また，大規模に建築用 60 キロ鋼のビルト $\mathrm{H}$ 組み立て高能 率溶接技術を鉄粉添加フラックスを適用したサブマージアーク溶接により確立し，SA440 鋼 $\mathrm{H}$ 形鋼が柱材として大 量に適用された晴海プロジェクトに適用された。

また，国家的プロジェクトである超鉄鋼プロジェクトに溶接材料設計の視点から参画し，継手疲労強度を高める 効果を有することで注目されていた低変態温度溶接材料の残留応力発生機構を基礎的に明らかにし, 低変態温度溶 材が効果を発現する条件を明確化した。さらに低変態温度溶材の耐低温割れ性や低合金鋼に適用した場合の耐食性 を明らかにし，高強度鋼溶接金属の設計指針を示した。

このように，社会ニーズに答える大入熱溶接技術開発や高強度鋼の溶接技術開発に扔いて，その実用化を図る上 で不可欠な溶接技術や適合溶接材料の開発など，同君が果たしてきた役割は非常に大きく，その貢献は多大なもの である。

また同君は, 日本溶接協会溶接棒部会の共研第 2 分科会 (鋼溶接部の水素測定方法の見直し), 共研第 3 分科会 （すみ肉溶接の耐ペイント性の評価方法の検討）の委員として, 実験デー夕の採取・蓄積, 規格原案の作成に尽力す るなど，社外でも溶接技術の進歩，発展に多大な貢献を果たしている。

以上のように，同君は進化する厚鋼板の溶接技術の開発捛よび応用普及において中核的な役割を果たしており， その業績は誠に顕著である。

\section{略}

1965年 1 月29日生

1988年 3 月 東北大学工学部 材料加工学科 卒業

1991年 3 月 東北大学大学院工学研究科 材料加工学専攻 博士課程前期の過程 修了

1991年 4 月川崎製鉄秼（現 JFE スチール(侏) 入社

鉄鋼研究所 鋼材研究部 強度・接合研究室 配属

2001年 4 月 (独) 物質材料研究機構 フロンテイア構造材料研究センター

(後に超鉄鋼研究センター)

構造体化ステーション 特別研究員 ( 3 年間)

2004年 4 月 JFE スチール(侏スチール研究所 接合・強度研究部 主任研究員

現在に至る 


\section{次世代材料・溶接技術、非破壊評価技術に関する 研究開発、若手育成ならびに学協会への貢献}

\section{正員田上稔君}

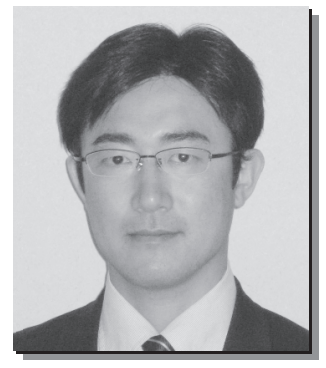

田上稔君は平成 3 年に石川島播磨重工業株式会社 (当時) の技術研究所接合部に入 社し, 高温超電導厚膜の接合技術の開発に従事後, (財) 超電導産業技術センター・ 超電導工学研究所に出向した. 出向先でも高温超電導材料の凝固現象の研究に従事 し, 「Pr1+xBa2-xCu3O7- $\delta$ 固溶体の単結晶成長に関する研究」で学位を取得した. 出向復帰後はレーザ溶接の鋼構造物への適用検討, 原子力向け自動溶接の開発, 中 性子ぜい化評価試験片への表面活性化接合の適用など次世代溶接の開発に従事した 後，非破壊評価技術のチームリーダに就任した。とくに，レーザ溶接の高構造物適 用検討結果は，現在進められているNEDO プロジェクト「鉄鋼材料の革新的高強 度・高機能化基盤研究開発」のレーザ関係の基礎となった。 また，適用の海外留学 経験 (TWI) もあり，国際的研究開発活動も行っている.

従来は非破壞検査・試験技術は業者が行う検査技術が中心であり，担当者は必ずしも溶接技術の知識が十 分とはいえなかった。たとえば，高合金材料の溶接部の非破壊検查には凝固組織に関する知識が要求される ほか, ボイラなど高温使用材のクリープ損傷に対する非破壞試験による余寿命評価には溶接部の組織など材 料・治金の知識が求められる。また，的確な非破壊試験・評価を行うには，溶接施工法の知識も必要である. 初めての橋梁へのレーザ溶接適用に関しても豊富な溶接技術の知識から日本で初めての鋼構造物向けレーザ 溶接継手の品質保証を実用化した。また, 近年社会問題となっている既設橋脚の検査・余寿命評価に対して も, 溶接技術の知識が大きく活かされている.すなわち，田上稔君は溶接技術にも精通した非破壊評価技術 の研究開発者であり, 従来の非破壊評価技術者とは異なった視点で溶接継手の非破壊検査, 非破壊試験・評 価に対してソリューションを含めた多くの成果を挙げてきた。もちろん，材料素材の非破壊評価に対しても 成果が多く，ジェットエンジン部材など貢献が認められて受賞もしている.

学協会活動も下記のように日本非破壊検査協会を中心に多くの活動を行っているほか，日本溶接協会，日 本機械学会でも委員会活動に貢献している. とくに, 論文査読委員会や編集委員会などの業務委員会での活 躍も多い.

近年は担当者としての研究成果だけでなく，チームリーダとして若手の教育・育成をしている.

以上のように, 田上稔君は研究実績, 社内外に対する技術貢献, 学協会に対する貢献が非常に大であり, 将来が嘱望されている研究者である.

$$
\text { 略歴 }
$$

昭和41年 12 月 15 日生

昭和 64 年 3 月 愛媛大学理学部物理学科卒業

平成 3 年 3 月 愛媛大学大学院理学研究科修士課程修了 (物理学専攻)

平成 3 年 4 月 石川島播磨重工業株式会社入社，技術本部 - 技術研究所 - 接合部配属

平成 4 年 4 月（財）国際超電導産業技術センター 超電導工学研究所 出向

平成 8 年10月 技術開発本部・生産技術センター・生産技術開発部 復命

平成 9 年 9 月 東京大学大学院工学研究科より博士 (工学) 取得

(平成13年 8 月 14年 7 月 : 英国溶接研究所客員研究員)

平成15年 7 月 技術開発本部・生産技術センター・生産技術開発部溶接・非破壊評価技術グル ープ 課長

〜現在に至る 


\section{石油精製用圧力容器および天然ガス輸送用クラッド鋼管の 溶接技術開発ならびに若手技術者の 指導・育成に貢献した業績}

\section{正員 茅 野 林 造 君}



被茅野林造君は，国内，海外の石油精製プラントで長期に渡って供用される石油精 製用圧力容器の各種高温損傷問題と溶接補修技術に関わる研究開発ならびに，主とし て海外の海底ガス田から腐食性天然ガスを輸送する溶接型クラッド鋼管の開発に携わ り，溶接材料技術分野の進歩・発展に貢献した。主な業績は次のとおりである.

石油精製圧力容器構造材料である $2.25 \mathrm{Cr}-1 \mathrm{Mo}$ 鋼へのステンレス鋼オーバーレイ溶 接部を対象として, 長期供用下の熱的脆化と水素脆化の重畳現象の把握と補修溶接 時に発生する割れを防止するための施工指針の提案を行った. 特にオーバーレイ溶 接ボンド部近傍における脆化に対する水素の影響を明確化し，水素の拡散，集積挙 動を数值解析により把握するとともに，補修溶接を行った際の割れ感受性に及ぼす 溶接熱サイクルの影響を明らかにした。

1）ステンレス鋼オーバーレイ部における水素の集積挙動の解明

補修溶接における水素の拡散, 再分配挙動を解析した結果, 補修溶接部直下においては, 境界部に集積し ていた水素が溶接熱サイクルにより, 拡散するものの, 大部分の溶接 HAZ 領域においては水素がほとんど拡 散せず高濃度のまま維持されることを明らかにした。

2）母材／ステンレス鋼オーバーレイ溶接金属境界部の脆化挙動の解明

熱的脆化と水素脆化が重畳したときの脆化度を切欠引張試験により定量評価を行い，焼戻しパラメータの 増加および水素曝露条件の高温高圧化により脆化が促進されることを確認した. また熱的脆化に比べて水素 脆化の寄与の方が大きいことを明らかにした。

3）脆化材の補修溶接割れ性に及ぼすオーバーレイ溶接金属/母材界面近傍における溶接熱サイクルの影響の解明 脆化材に対して補修溶接を行うときの溶接割れ性を斜め $\mathrm{y}$ 型拘束割れ試験により評価し, 割れ感受性には 熱的脆化と水素脆化度および残存オーバーレイ厚さを介した補修溶接熱サイクルの影響があることを明らか にした。

4）多層盛補修溶接時のオーバーレイ溶接金属／母材界面部における割れ感受性に及ぼす水素の影響の解明

実機多層盛り補修溶接モデルの水素の再分配, 集積挙動の数值解析を行うとともに, 熱的脆化と水素脆化 の重畳を実験的に再現した試験材に対する補修溶接試験を行い，割れ感受性の評価を行い，補修溶接施工の 考え方として, 熱的脆化と水素脆化の重畳した脆化度の把握, 補修溶接による発生応力と脆化改善有無を考 慮して新たな割れ発生の可能性を評価した後に脱水素運転採否を決定する新たな指針を示した.

また天然ガス輸送用溶接構造クラッド鋼管の製造にあたっては，パイプラインの安全性要求の高度化を背 景に，低温勒性に優れたクラッド鋼板および溶接施工技術の開発に携わり，商用化した。

1）天然ガス輸送管用高靯性クラッド鋼板の開発

API 5L-X65 の強度レベルを維持しつつ，溶接 HAZ 部においても-40ㄷ ラッド鋼板を開発した。

2) 天然ガス輸送管用高勒性 X70 クラッド鋼板の開発

合金元素のさらなる適正化を図ることにより $-40^{\circ} \mathrm{C}$ の低温勒性を維持しつつ，X70 グレードの強度レベルを も満足できるクラッド鋼板の開発を行った。また現地敷設時の鋼管の周溶接において二相ステンレス鋼や Ni 基合金溶接材料を適用した溶接施工技術の開発を行った。

また同氏は, 溶接学会 若手会員の会において若手技術者への意識高揚, 溶接治金研究委員会, 溶接構造研 究委員会においても各種構造材料の溶接治金現象, 力学的挙動の解明を進めるなど, その活動は一企業内に 止まることなく，溶接界へ貢献している.

以上のように同氏は，石油精製圧力容器の構造材料の溶接補修に関する研究開発，天然ガス輸送用クラッ ド鋼管の溶接技術開発で顕著な業績を残し、溶接技術の進歩発展に大いに寄与した。また、経歴の職位にあっ て後進技術者の指導・育成も的確に行ってきている. 更に, 溶接学会を中心とした公的な活動を通じ, 溶接 界のレベルアップにも積極的に尽力し，功績は多大である. 
1968年 4 月18日生

1991年 3 月 大阪大学 工学部 生産加工工学科卒

1993年 3 月 大阪大学 大学院工学研究科 生産加工工学専攻 博士前期課程修了

1993年 4 月 侏日本製鋼所 入社 室蘭研究所 鉄鋼研究部配属

2004年10月 室蘭研究所 材料開発グループ 主任研究員

2006年 3 月 工学博士 (大阪大学)

2008年11月＼cjkstart室蘭研究所 塔槽・クラッド製品開発グループマネージャー 現在に至る

1996年～＼cjkstart溶接学会 若手会員の会 委員

1997年～溶接学会 溶接治金研究委員会 委員

1997年～溶接学会 溶接構造研究委員会 幹事 


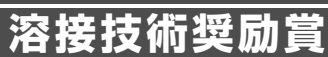

溶接技術奨励賞は, 昭和 63 年 10 月に創設され, 各支部において溶接・接合に関し, 研究・開発・改良あ るいはその実用化の功績顕著な方にその地域の支部長から贈られます。

\section{北海道支部}

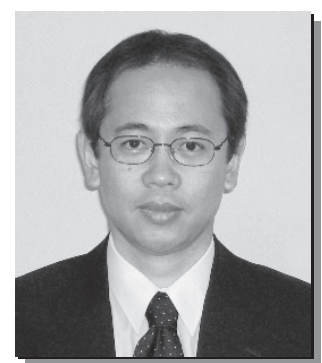

片 山 直 樹 氏 昭和36年 7 月 4 日生 北海道立工業試験場
片山直樹は, 昭和 60 年 4 月，北海製鑵（株）に入社し，直ちに関連会社のクロ ーバー電子工業 (株) に出向し, 高密度多層プリント配線基板の技術開発に従事し た。

平成 4 年 10 月，北海道立工業試験場に採用され，現在まで，表面処理，レーザ 加工, 電子部品実装等の金属加工 · 接合技術に関する研究開発と技術の普及活動 に従事している。これまで, 電子部品実装関連の接合技術において, 全国の公設 試験研究機関に先駆けて，はんだ材料の鉛フリー化に関する研究開発に着手し， 大学との共同研究や国家プロジェクトへの参画等により，鉛フリーはんだ付け技 術や標準化に関する研究開発を行った.

平成 11 年に大阪大学接合科学研究所と共同研究を行い，鉛フリーはんだのはん だ付性に及ぼす各種めっき皮膜の影響を明らかにした。

平成 12 年に新エネルギー・産業技術総合開発機構の「鉛フリーはんだ規格化の

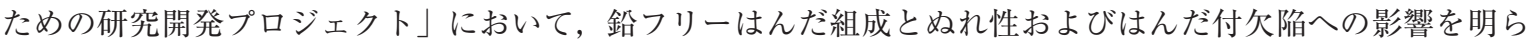
かにした。

平成 14 年に新エネルギー・産業技術総合開発機構の「環境負荷低減化に対応したはんだ接続に必要な試験 方法等の標準化プロジェクト」において，溶融温度範囲測定方法を検討し，鉛フリーはんだ試験方法 (JIS Z 3198）の制定に貢献した.

平成 11 年から 16 年まで（財）製造科学技術センターの IMS (Inteligent Manufacturing System) プログ ラムによる国際プロジェクト「環境対応次世代接合技術の開発（EFSOT）」に参画し，フローソルダリングプ ロセスにおける浴組成管理基準を確立した。

現在も，鉛フリーはんだの実用課題に関する研究プロジェクトに参加するなど，国内でも鉛フリーはんだ に関して精力的に研究開発を進めている。これらの研究成果は, 国内外の学会等で発表すると共に, 道内に おける講演会，講習会等において積極的に普及活動に努めており，道内企業の競争力の向上に多大な貢献を している。また，業界活動は平成 11 年から溶接学会 Mate 実行委員を，平成 20 年から溶接学会代議員並び に溶接学会誌会員モニ夕を務めており，片山直樹氏が溶接・接合技術の発展・普及に貢献した功績は顕著で ある。 


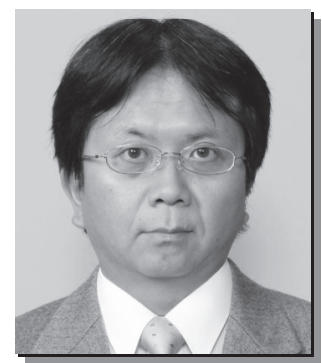

佐 藤 善 久 氏 昭和38年 7 月 22 日生 福島県ハイテクプラザいわ き技術支援センター 主任研究員

佐藤善久氏は，昭和 62 年に東京農工大学工学部生産機械工学科を卒業後，アル プス電気株式会社勤務を経て, 平成 4 年に福島県の技術吏員となり, 福島県ハイ テクプラザに配属された，以来，県内企業を対象とした溶接・接合に関する指導 と試験・研究に関する業務を行っている.

日々，溶接物や試験片の物性試験や非破壊検査等に携わりながら, 平成 4 年度 からは福島県溶接技術競技会の審査委員を務めている。より高度な技術相談にも 対応すべく，日々，研鑽を積み，平成 9 年度にはWES8103の 1 級にも合格して 地域の溶接技術を広く支援・指導している.

研究では，地域ニーズに基づいたテーマを多数実施して溶接技術の振興や製造 技術の開発を行う等, 地域産業の発展に寄与している。専ら, 平成 6 年から 12 年 までは炭酸ガスレーザと YAG レーザを用いて，高速でひずみが少ない溶接技術の 開発と実用化について研究した。平成 13 年には活性金属材料の溶接施工条件と品 質評価技術について研究し，分光色差計を用いた新たな手法でチタン合金の酸化 状況を評価した。平成 14 年にはアルミニウムの拡散浸透処理された鋼板を部分的 に溶射によって被覆することによる，溶接部の高温耐性向上について研究した。平成 15 年から 17 年までは 抗菌ステンレス鋼板の溶接性と抗菌性の関連について研究し，一般的な SUS304 を抗菌化する技術を開発し た. 平成 19 年からは，電子や医療機器の分野で用いられることが多くなってきた板厚 $0.5 \mathrm{~mm}$ 以下の極薄ス テンレス鋼板に関する高品位で経済性に優れた溶接に取り組んだ。緊縮かつ硬直したプラズマアークの活用 と，正確な位置決め機構や同期制御を有する治工具を開発することによって，それらを応用した企業の新製 品開発に貢献した。

以上のように，同氏の溶接・接合技術の発展に寄与した功績は顕著である.



柴 田 公 博 氏

昭和 22 年 4 月 1 日生 宮城工業高等専門学校 材料工学科 教授

柴田公博氏は昭和 44 年 3 月横浜国立大学工学部金属工学科, 昭和 46 年 3 月同 大学院工学研究科修士課程金属工学専攻を修了，(株) 神戸製鋼所に勤務後，昭和 52 年 3 月に東北大学大学院工学研究科博士課程金属加工学専攻を修了し, 合金の凝 固過程におけるミクロ組織形成機構に関する研究で工学博士の学位を受与した。そ の後, 日本学術振興会の奨励研究員を経て, 昭和 55 年に日産自動車（株）に入社 した。同社の総合研究所において，主に環境エネルギー問題に関連した車両の燃 費向上および衝突安全性能の向上のための材料技術に関する研究開発に従事した。 その間, 名古屋大学を初めとする複数の大学の非常勤講師も務め, 平成 17 年 4 月 から現職，技術者教育・研究活動を続けている.

同氏の研究対象は構造用材料，生産加工技術（特に，溶接，鋳造，表面処理技 術)，レーザ加工技術など，材料工学の広い分野にわたるが，特にレーザ加工技術 分野で大きく貢献している。テーラードブランク材のレーザ溶接技術，アルミニ ウムシリンダーヘッドのレーザ肉盛技術，駆動部品のレーザ焼入れ技術，車体用 アルミニウム合金のレーザ溶接技術に関して多くの研究開発を行い，実用化に貢献した。これらの成果は， 国内外の学会等において多くの講演や論文として発表している.現在は，主にレーザによる異種材料の接合 や表面改質の研究を行っている. 社会的貢献として, JICAの溶接技術者研修コースの講師や技術科学大学 4 年生にレーザ溶接の実務訓練・研究指導などを行ってきた。学協会活動としてレーザ加工技術関連の国際会 議における企画や編集委員, 座長などを, また日本金属学会の評議員や各種委員, 溶接学会の全国大会運営 委員などを務めてきた．現在，日本溶接協会のレーザ加工技術研究委員会の幹事長，溶接学会東北支部商議 員などの任に着くほか，溶接学会東北支部研究会等での講演などを継続し，東北地域における溶接技術の発 展および振興に貢献している.

以上のように，柴田公博氏の溶接技術の発展に寄与した功績は誠に顕著である. 


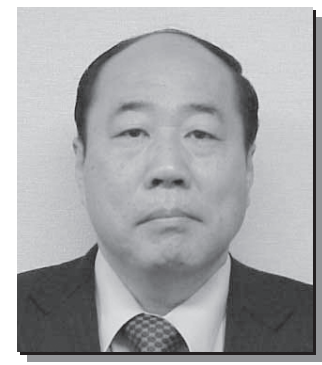

須田 一師 氏 昭和24年12月19日生 日鐵住金溶接工業(侏) 海外事業企画センター 部長

の発展に努めている.

以上のように，同氏の溶接技術に関する研究・開発ならびに実用化に果した功績は誠に顕著である.
須田一師氏は, 昭和 49 年 3 月日本大学大学院生産工学研究科機械工学専攻修士 課程を修了後，日鐵溶接工業株式会社（現 日鐵住金溶接工業株式会社）に入社.

研究所在籍中には，主にガスシールドアーク溶接材料の開発や新溶接方法の開 発に携わり，造船自動化新溶接法，溶接電流変化方式全姿勢自動溶接法「PAW$\mathrm{AB} 」 の$ 開発・実用化に努めた。その後も，耐熱鋼用ガスシールドアーク溶接ソリ ッドワイヤおよびフラックス入りワイヤを開発するとともに高速増殖炉「もんじ ゆ」のナトリウムダンプタンクへの狭開先溶接法「ループナップ法」が実施工に 適用された。また，貨物の海上輸送効率化のためにコンテナ船の大型化傾向に対 応すべく, 造船分野で高能率施工技術として採用されている $\mathrm{EGW}$ の更なる高能 率溶接法の開発に取り組み, 溶接施工技術を含めた溶接装置 ( 2 電極 VEGA 法), 溶接材料を開発し, 数多くのコンテナ船に適用され, 優れた実績を残している.

また，溶接学会の全国大会や溶接法研究委員会等で研究論文を発表，日本溶接 協会溶接棒部会技術委員会でも各分科会主査·幹事を歴任，その内容について講演 するとともに平成 10 年からは，溶接学会溶接法研究委員会の幹事として溶接技術



長 岡 茂 雄 氏 昭和 24 年 6 月 10 日生 (株)神戸製鋼所 溶接カンパ ニー 技術開発部 主任研究員
長岡茂雄氏は，1968 年に(株神戸製鋼所へ入社後，被覆アーク溶接棒やフラック ス入りワイヤ (以下, FCW) などの各種溶接材料に関する研究・開発に従事し, 特に, FCW と溶接施工法の開発および実用化において, 当該業界における溶接技 術の進歩に大きく貢献してきた。主な業績は以下の通りである。

（1）1980 年代, 当時では新溶接材料として誕生した FCW の開発を手がけ, 全姿 勢溶接用 FCW やすみ肉用 FCW などを開発した。高能率な溶接が可能である うえ, 被覆アーク溶接棒のような技量を必要とせず，ビード外観やビード形 状がソリッドワイヤに比べて優れているなどの特長を有していることから，造 船分野や橋梁分野を中心に急激に FCW 化が進められた。このような溶接法 の変化に対し，材料開発・実用化の面から大きく貢献した.

（2） 1990 年代，タンカーのダブルハル化が義務化され，すみ肉溶接長が約 $30 \%$ 増 加したことから，すみ肉溶接の高速化要求が高まった。これに対して，小極 間 2 電極高速水平すみ肉溶接法とその溶接材料を開発した. 本溶接法と材料 は，国内外の多くの造船所において採用されており，溶接技術の進歩に大き く貢献した.

（3）その他，1990 年代後半からは，単電極でのすみ肉溶接の高速化に対応した FCW の開発や， 3 電極での 高速すみ肉溶接法とその溶接材料開発などを行い，ますます高まっている構造物製作の生産性向上に大 きく貢献している。

同氏の功績により，（社）溶接学会妹島賞（2008 年），（社）日本溶接協会溶接注目発明賞（1999 年及び 2008 年) 並びに発明協会近畿地方発明奨励賞（2001 年及び 2008 年）をそれぞれ受賞している．以上のように，同 氏は当該溶接技術に関する研究開発並びにその実用化を通じて，長年に亘り日本の産業界に貢献し，その功 績は誠に顕著である。 


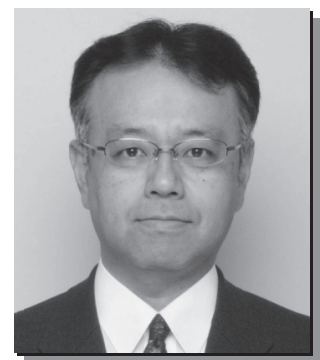

矢 埜 浩 史 氏 昭和37年10月 2 日生 JFEスチール(株) スチール 研究所 接合・強度研究部 主任研究員
矢埜浩史氏は昭和 63 年 3 月大阪大学大学院工学研究科溶接工学専攻を終了後, 川崎製鉄株式会社（現 JFE スチール株式会社）に入社．以降研究開発部門に在籍 し，建築，橋梁，造船分野における溶接材料に関する研究を行い，溶接の高能率 化および溶接部の高性能化に大きく貢献している。 また，電子ビーム溶接，レー ザ溶接，高耐候性鋼の溶接などの開発にも取り組み，溶接技術の発展に寄与した。

とくに，建築分野における鉄骨の溶接の研究に精力的に取り組み，建築大入熱 溶接用高 HAZ 勒性鋼に適用するボックス柱角継手の溶接では，板厚：60mm まで の 1 パス大入熱溶接 $(50$ 万 $\mathrm{J} / \mathrm{cm}$ 程度)の溶接金属組織微細化のために，溶接金属 中の有効 $\mathrm{B}$ 量均一化技術を新たに開発し，ボックス柱内面側を含む溶接金属の全 体の高勒性化を達成した。開発した溶接材料およびその溶接施工方法は東京駅周 辺の再開発など数多くの物件に採用されている.

また，フェライト系ステンレス鋼の溶接の研究においても，TIG 溶接溶融池の 湯流れを考慮した溶接金属酸素量制御（鋼板 $\mathrm{Al}$ 量，シールドガス組成制御）によ

る溶込み性向上技術を溶接学会の講演大会や日本溶接協会の特殊材料溶接研究委 員会に発表・報告し, 学会・講演活動を精力的に行うとともに，日本溶接協会溶接棒部会や溶接治金委員会 の委員としても溶接技術の発展に努めた.

以上のように同氏は溶接技術において研究・開発ならびに実用化に果した功績は誠に顕著である.

\section{東海支部}

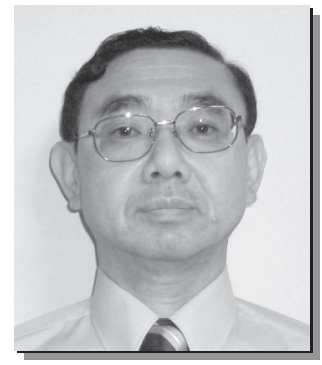

斉 藤 直 樹 氏 昭和30年 5 月 20 日生 新日本製鐵(株) 技術開発 本部 名古屋技術研究部
斉藤直樹氏は昭和 56 年大阪大学大学院工学研究科を卒業後，新日本製鐵（株） に入社し，下記に述べるように，高度に耐脆性破壊特性が要求される低温装置や 大型構造物に適用される溶接構造用鋼材の開発を通じて, 我が国における同分野 での溶接構造物の安全性の向上に多大な寄与をした。

1）耐脆性破壊特性に優れた $9 \% \mathrm{Ni}$ 鋼の開発

地上式 LNG 貯槽タンクの内槽材として使用されている $9 \% \mathrm{Ni}$ 鋼において, 超 大型 LNG タンクの建設に必要な極厚 $9 \% \mathrm{Ni}$ 鋼を開発するという社会的な要請が あった。これに対し, 同氏は, 溶接部における耐脆性破壊発生特性および母材の 耐脆性き裂伝播停止特性における鋼成分や熱処理の影響などを調べ，両特性に優 れた新しい $9 \% \mathrm{Ni}$ 鋼を開発した。開発鋼材は，我が国に建設された世界最大の地 上式超大型 LNG タンクを始めとして国内外の LNG タンクに適用されている.

2) 大入熱溶接が可能な低温用鋼材の開発

水海域で操業される海洋構造物用の鋼材において, 経済性と安全性の要求から 大入熱溶接が可能でかつ高い HAZ 勒性を有する鋼材の開発が要望された。これに 対し，同氏は，鋼中の窒化物や硫化物からなる複合析出物を変態組織制御に利用し，かつ鋼成分を最適化す ることで，大入熱溶接や低温下においても勒性低下が小さい高強度鋼を開発した。本鋼は，海洋構造物や LPG 船などに適用された。

3）ペンストック用厚手高張力鋼の開発

超高落差揚水発電所に適用される極厚高張力鋼では, $950 \mathrm{MPa}$ 級の高い引張強さと同時に, 優れた耐脆性 き裂伝播停止特性が要求される。同氏は，これらの特性を両立させるために，TMCP 技術を適用した新しい 製造法の実用化に貢献し，開発鋼材は我が国水力発電所の建設に適用された。

また，同氏は，平成 10 年度から 19 年度までの 10 年間にわたり，東海支部幹事を中心に，商議員，評議 員，副支部長を歴任し，支部活動および 14 年度秋季全国大会開催に尽力した。以上のように，同氏は鋼材の 開発を通じて我が国の産業に，そして学会支部活動を通じて接合技術の普及・発展に貢献した功績は大きい。 


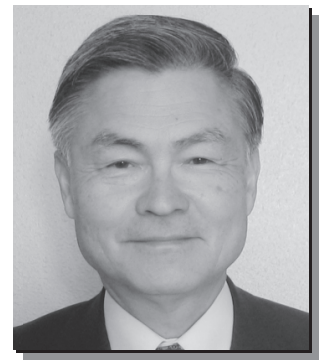

大 村 博 彦 氏 昭和 20 年 12 月 12 日生 東海鋼管株式会社 技術顧問
大村博彦氏は, 昭和 46 年名古屋市工業研究所に入所以来溶接関連の研究・開発 の業務に専念し，とくにろう付け技術の研究に数々の業績を上げ，また学協会活 動を通じ溶接技術の普及にも尽力して来た。主な業績は次の通り.

(1)異種材料ろう付けの理論と応用の確立

同氏は名古屋市工業研究所にて吉田亨博士のもとで標記のテーマで研究を行い, 母材の溶解一晶出のモデルを解明し，理論を確立し多種の応用を行った。たとえ ば，炭素鋼ろう付継手の強度の向上，ステンレス鋼と炭素 鋼の鉄箔挿入銅ろう 付の開発，超硬合金と鋼のろう付の改善などである.

(2)溶接技術の普及

永年，名古屋市工業研究所に拠点を置く中部溶接振興会世話役として活躍し溶 接技術の振興・普及に貢献した。本会は昭和 31 に関口名大教授により開設され溶 接工の訓練教育から，技術講演まで幅広い活動をしてきたが，当地区の貴重な伝 統を守り継続させた. 年 2 回の講演会と見学会を毎年行い一昨年は 50 周年を迎え た。

(3)学協会活動 務めた。この間東海支部溶接研究会，講演会を 15 回主催し溶接技術の啓蒙に努力した.

特に，2005 年東海支部で溶接協会ともに開催した HUBTEC 2005-レーザ溶接総合技術展にて同氏は企画か ら運営までを一環して担当し，東海地区の溶接技術の普及に努めた。

また溶接協会では 30 年以上にわたり貴金属ろう部会技術委員会幹事を担当し，ろう付技術の研究・開発に 携わりろう付継手性能の大幅な改善と品質向上に寄与するとともに，ろう付関連技術の普及・発展に貢献し た。

また，溶接協会愛知県支部では，14 年にわたる支部役員と愛知県溶接技術競技会委員を務め，支部活動を 活性化させ，競技会の円滑な運営と後輩への技能伝承に貢献した.

\section{中国支部}

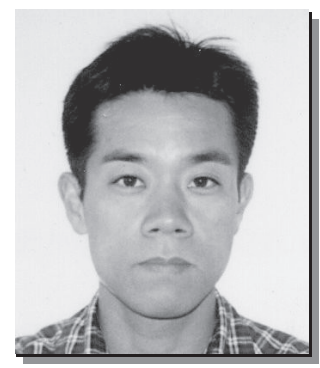

坂 村 勝 氏 昭和 41 年 5 月 18 日生 広島県立総合技術研究所東 部工業技術センター加工技 術研究部副主任研究員

坂村勝氏は, 平成 4 年京都大学大学院工学研究科金属加工学専攻修士課程を修 了し，住友金属工業（株）に入社した。その後，平成 8 年に広島県立東部工業技術 センター (現；広島県立総合技術研究所東部工業技術センター) に研究員として採 用され，溶接・接合に関する研究開発及び県内企業への技術指導を行ってきた。

同氏は，主として県内企業からのニーズに基づいて研究開発を行い，県内企業 の溶接・接合技術の発展に寄与してきた。以下に主な研究実績を挙げる.

(1) 異種金属の拡散接合技術の開発

(2) チタン製小型部材の歪無しレーザ溶接技術の開発

(3) レーザ局部チル化による，球状黒鉛鋳鉄製加工定盤の耐摩耗性向上技術の開発

(4) 放電プラズマ焼結法による Ni バインダー超硬合金の開発

(5) 摩擦攪拌接合による，アルミニウム接合部の陽極酸化処理後の変色防止技術開 発

(6) 鋼板用摩擦攪拌点接合技術の開発

なお，同氏は平成 15 年に溶接管理技術者特別級及び INTERNATIONAL WELDING ENGINEER を取得しており，溶接技術に関しての見識は十分である。また，平成 14 年度より溶 接学会中国支部商議員 (幹事) 平成 18 年度より日本溶接協会中国地区溶接技術検定委員会委員として，中国 地区の溶接技術の発展・普及に貢献した。

以上のように，坂村勝氏が溶接技術の研究開発・普及に寄与した功績は誠に顕著である. 


\section{九州支部}

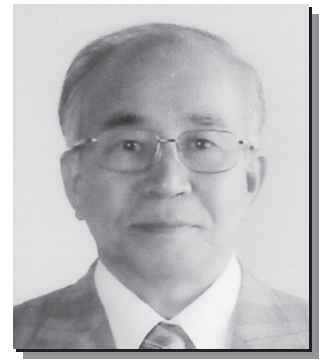

山口喜久次 氏

山口喜久次氏は昭和 31 年に九州大学工学部造船学教室に着任し，平成 13 年 3 月に停年退職するまでの間, 溶接力学, 熱塑性加工学, 大型溶接構造物の㾉労強 度及び不安定破壊強度評価に関連する研究及び教育に従事した。

溶接力学に関連する研究としては, 溶接残留応力及び溶接変形の定量的評価及 び溶接割れ防止対策技術に関して，沉用の計測機器の発達が不十分であった時代 にも関わらず，高精度な計測を可能とする種々の手法を考案，実装することで， 研究の発展に大いに寄与した。また，片面自動溶接における突合せ溶接継手の終 端割れ防止対策について有用な知見の解明に協力した。

船殼材料の加工に際しての撓鉄 (曲面創成) 加工や溶接変形矯正に使用される線 状加熱に関して，ガス炎から鋼板に供給される熱量の定量的把握のために必要と される実験・計測装置の構築や，計測対象である変形成分を精度良く計測するた めの実験手法の検討や計測装置の構築を行い，当該分野の研究発展に大いに寄与した。この結果は，従来は 作業者の勘と経験のみに頼っていた・撓鉄・変形矯正作業に対して理論的な裏付けを与えることに貢献した.

疲労強度研究においては, 疲労き裂進展実験の全自動化及びき裂先端近傍で生じる塑性ひずみのヒステリ シス挙動の高精度計測を可能とした, 全自動疲労試験システムの構築に大いに寄与した。本試験システムを 用いた種々の疲労試験から, RPG 荷重という疲労き裂成長挙動を記述するための新たなパラメータが提案さ れ，同基準に基づく疲労寿命評価の有用性が示されている.

不安定破壊強度評価に関しては，表面き裂材の弾塑性 COD 推定手法の構築に貢献すると共に，高速載荷中 のき裂線上の局部温度上昇を連続的に測定できる実験システムの構築や，広範囲のひずみ領域における応力 〜ひずみ関係の測定システム構築など，任意ひずみ速度・温度場における不安定破壊強度評価手法の確立に 対する貢献も著しい.

一方，学生実験，卒業論文及び修士論文に関連した実験に際しては，学生及び院生に対して情熱を持って 指導に当たり，その高邁な人格と真摰な態度，強い責任感に満ちた教育姿勢によって学生及び院生に深い感 銘を与え，多くの優れた人材の輩出に貢献した.

以上のように，同氏の長年に渡る溶接・接合技術の発展に寄与した功績は顕著である. 


\section{滀接技術普及賞}

溶接技術普及賞は平成 2 年 11 月に創設され，各支部において，溶接・接合に関し，講座・講習会の講師， 見学会, 展示会の企画・実施等により, 技術・技能の普及, 発展に著しく貢献した方にその地域の支部長か ら贈られます。

\section{北海道支部}

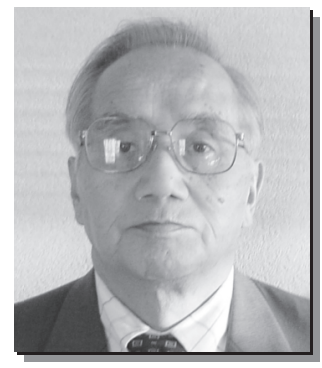

吉 田 隆 男 氏

吉田隆男氏は，昭和 36 年新日本製鐵(株)入社, 昭和 38 年室蘭工業大学短期大学 部機械化卒業，昭和 42 年産業技術短期大学鉄鋼工学科卒業室蘭製鉄所設備部に勤 務し，鉄鋼設備の整備及び工事に従事する中で，循環製備品の品質改善を目的に 肉盛溶接施工の標準化を推進し品質の安全化及び向上を図った。また, 自溶性溶 射及びアーク溶射装置を導入，それらの施工技術を確立し耐摩耗及び耐食技術の 向上を図った。

高炉建設工事では，本体鉄皮の全 6 シームを同時に溶接する SES 自動溶接法を 開発し，高品質かつ高効率な施工に貢献した。また，連続鋳造設備ではロールロ ーラの対摩耗を目的とした肉盛溶接材料及び 3 電極 MIG 自動溶接機を開発（特許 申請）した。

また，同氏は技術士（金属部門，金属施工·溶接），溶接管理技術者（特別級）， 労働安全コンサルタント，QMS 審査員補 (コンピデンス)，1級管工事及び土木施工管理技士等の資格や知識 を生かし，ガス溶接技能講習，アーク溶接特別教育及び職長·安全衛生責任者教育などの講師，また知事より 北海道技術アドバイザーの委嘱を受け各種の技術相談や指導などで活躍され，更に北海道地区溶接技術検定 委員や第 35 回全国溶接技術競技会の実行委員及び道主催の「移動大学」の講師等を通じて道内における溶接 技術の向上に尽力した。

現在は，技術士事務所を運営し，各種技術鑑定や発電設備のボイラー，タービン等の安全管理審査業務に 従事し，また平成 17 年「溶接施工技術に関する講演会」，平成 18 年「溶接学会秋季全国大会」で講演するな ど，溶接技術の普及に対する貢献は顕著である。また道知事より PCB 廃棄物処理事業 監視円卓会議委員の 委嘱を受け処理施設の適確な整備·操業等で尽力し, 更に平成 19 年から, 室蘭工業大学非常勤講師として「信 頼性工学」を担当し学生との信頼のコミュニケーションを基に講義を行っている. 


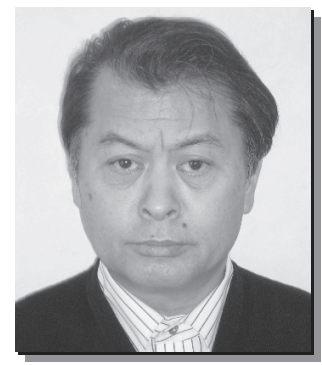

佐々木 世 紀 氏 昭和26年3月13日生 東北少年院＼cjkstart法務教官

佐々木世紀氏は，昭和 49 年 4 月法務省矯正局八街少年院勤務を経て昭和 59 年 4 月同東北少年院職業訓練溶接科法務教官に就任, その後専門官の業務に従事し, 現在上席専門官に至っている。 その間職業訓練大学校短期過程溶接科を修了した。

同氏は，正常健康な社会復帰を目指す青少年たちに対し，困難な矯正教育の環 境にも拘らず積極的に溶接技術・技能の教育訓練を約 25 年の長きにわたり実践 し，社会のニーズに対応して大きな成果を挙げている.

平成 59 年に被覆アーク溶接技術評価試験 (JIS Z 3801) に初挑戦以来, $\mathrm{CO}_{2}$ 半自 動溶接（JIS Z 3841），ステンレス鋼溶接（JIS Z 3821）の技術評価試験へと逐次溶 接施工法の適用資格拡大に努力し，斯界情勢を洞察して青少年たちの将来を見据 えた職業能力開発に尽力した.また, 平成 8 年には, チタン溶接技術評価試験 (JIS Z 3805）資格取得の高水準溶接技能者育成に成功し，上述の 4 種目の溶接施工法に基 づくJIS 有資格者は，これまで相当数の多きを数えるに至っている.

また，日常の溶接訓練カリキュラムの他，技能の深度化を図り，ステンレス 鋼・チタン・アルミニウム溶接講習会を継続して計画実施し，外部講師の技術力を導入しながら青少年たち の能力向上に努めている. 関連応用技術として, ALC 溶接施工法・高圧ガスボンベ取扱い安全講習会なども 企画運営している.

さらに，労働安全衛生法に基づく公的資格の付与のために「ガス溶接技能講習」および「アーク溶接」・ 「研削といし取替え」・「粉じん作業」ならびに「酸素欠乏・硫化水素危険作業」の特別教育講習会をそれぞれ 立案開催している.

以上のように佐々木世紀氏の長年にわたる青少年の矯正教育訓練としての溶接技能者の育成，ならびに溶 接技術の普及に貢献した功績は誠に顕著である.

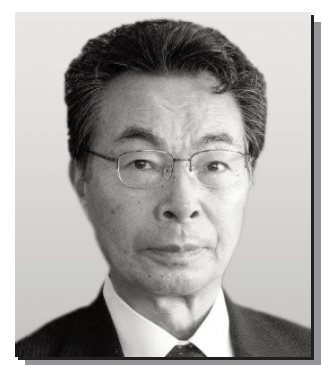

小田桐宏 氏 昭和 18 年 5 月 23 日生 小田桐鉄工企画 代表

小田桐宏氏は昭和 35 年合資会社十川鉄工所に入社以来，49 年間にわたり金属製 品の製造一筋でものづくりに情熱を燃やし，特に溶接においては優秀な技能を持 ち，溶接競技大会において県大会一位（昭和 56 年 第 11 回青森県溶接技術競技大 会 半自動溶接の部), 東北地区大会優良賞 (昭和 56 年 第 11 回東北六県溶接技 術競技大会 半自動溶接の部)，全国大会でも優良賞（昭和 56 年 第 27 回全国溶 接技術競技大会）を受賞するなど多くの実績がある。ガス溶接，アーク溶接，半自 動溶接に高い技能を有し，建築および土木工事における金物製作では 40 年間にわ たって大手建設会社の一次下請けとして官公庁等の建設現場代理人を務めた経歴 を持つ。特にりんご等の青果物長期保存に使用する CA (Controlled Atmosphere) 冷蔵貯蔵施設の各種ガス調整機器の製作および配管工事においては信頼が厚く, 多 くの施工実績を有する。

これらの溶接に関する経験，技能を継承させるため，後進の育成においては人 一倍精力的に活動してきた。平成 13 年〜18 年にかけて弘前大学教育学部で，平成 14 年〜現在まで青森県立弘前高等技術専門校で，平成 16 年〜現在まで青森県立柏木農業高校において講師と して出向き，自ら作成した指導マニュアルに基づき，溶接技術の普及に尽力してきた。さらに，平成 16 年か らは青森県職業能力開発協会における「鉄工」職種部門の青森県技能検定委員を務め，業界の発展に寄与し ている.

平成 20 年には溶接技能の功績が認められ，中央職業能力開発協会において高度熟練技能者に認定されてい る.

以上のように，小田桐宏氏の長年にわたる溶接技術の普及・発展に寄与した功績は顕著である. 


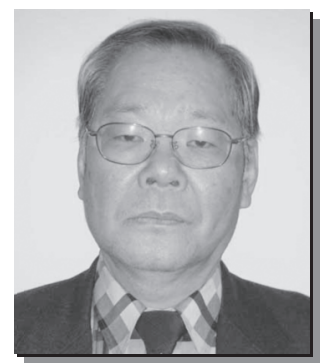

金 原 利 雄 氏 昭和 27 年 10 月 27 日生 (株)東芝 京浜事業所 溶接センター 主務
金原利雄氏は, 昭和 46 年に東京芝浦電機株式会社鶴見工場に入社以来, 主とし て核融合, 加速器等の溶接施工技術ならびに溶接装置の開発とその技術指導に貢 献し，溶接技術の普及に大きく寄与した。同氏の溶接技術の普及に関する主な業 績を挙げると以下のとおりである.

（1）超高落差ポンプ水車への CES 溶接（消耗ノズル式エレクトロスラグ溶接）の 適用をはかり，厚板溶接技術の普及に貢献した。

(2) 半導体製造装置の単結晶引上げ装置の製造において, ステンレス容器ヘレー ザ MIG アークハイブリッド溶接を初めて実用化するとともに A-TIG 溶接の 適用をはかるなど製造合理化に向け，新溶接技術の普及に貢献した。

（3）ピックス粒子検出用スペクトロメータであるATLAS 用のアルミ配管自動溶 接装置を開発し, スイス CERN における現地溶接施工に適用した. 現地施工 においては, 溶接技術の現地指導を行い, 溶接品質を確保することで 2008 年 9 月のビーム初周回の成功に大きく貢献した.

(4) 九州大学核融合装置 (QUEST) 用トロイダルコイルの $80 \mathrm{~mm}$ 厚さの銅溶接に 対して電子ビーム溶接を適用した施工技術を確立し，厚肉銅溶接技術の普及 に貢献した。

（5）国際熱核融合装置 ITER 真空容器セクタモデルの製作において，ステンレス製大型二重壁構造物の溶接 工法を確立し，今後計画される実機規模装置製造に大きく貢献した.

以上のように, 同氏が新溶接施工技術の実用化・指導に貢献し, 高度化する溶接施工技術の普及に寄与し た功績は誠に顕著である。

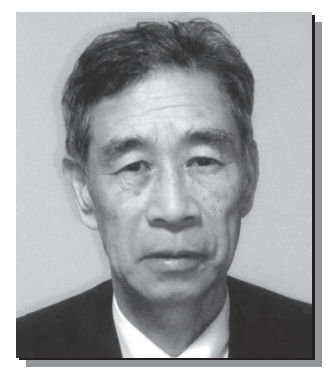

草 間 洋 一 氏 昭和 17 年 3 月 2 日生 長野県商工会連合会 中信支所 専門指導員
草間洋一氏は，昭和 38 年に工学院大学専修学校機械科を卒業後，科学技術庁金 属材料技術研究所, 特殊溶接研究室に勤務して, セラミックスのプラズマ溶射皮 膜層強度に関する技術開発に従事. 昭和 40 年 9 月に同研究所, 溶接研究部圧溶研 究室に総理府技官に採用され, 耐熱材料の電子ビーム溶接部の高温顕微鏡による 組織変化に関する研究に従事した。

昭和 43 年に長野県工業試験場金属部に入所して溶接技術の開発に取り組み，球 状黒鉛鋳鉄のアプセット溶接継手接合面特性と溶接条件, 熱処理条件の関連性に 関する研究を行うとともに, ねずみ鋳鉄の連続冷却変態図 (SH-CCT 図) を作成し て鋳鉄の溶接熱影響部の硬化防止条件を提案し, 県内企業, 溶接協会会員, 熱処 理研究会などで鋳鉄接合継手に関する研究成果発表を積極的に行った。また， SUS329 ステンレス鋼や冷間圧延鋼板などのプラズマアーク溶接に関する研究開 発にも従事する傍ら, 昭和 43 年 5 月からガス溶接技能講習学科講師, 昭和 44 年 8 月からはアーク溶接特別教育講師を務め, 県内溶接関連企業の技術向上, 技術 発展に貢献・寄与した。

昭和 52 年 4 月からは長野県精密工業試験場加工部に勤務して, YAG レーザによる精密溶接加工に関する 研究テーマに取り組み, ステンレス鋼や異種金属材料におけるレーザスポット溶接技術の進化と普及・発展 に貢献した。

また, 昭和 55 年と平成 19 年に信州大学工学部にて開催された溶接学会秋季全国大会においては, 長野大 会開催実行委員として積極的に企画・準備活動などに取り組み，大会の成功に大いに貢献した功績は誠に顕 著である。 




小 林 和 昌 氏 昭和 22 年 3 月 19 日生 一般社団法人 長野県溶接 協会

事務局長

小林和昌君は, 昭和 45 年 3 月 千葉工業大学工学部 機械工学科卒業後, 直ち に長野県職員として長野県諏訪地方事務所に配属勤務し, 昭和 48 年 4 月, 長野県 工業試験場へ異動勤務後, 研究員, 主任研究員, 金属材料部長を歴任し, 平成 17 年 4 月長野県工業技術総合センター材料技術部門長, 平成 19 年 3 月退職まで, 金 属材料, 溶接技術分野の研究, 技術指導を担当し, 溶接技術の普及と向上に貢献 した。また退職後は，（社）日本溶接協会長野県支部事務局長として，溶接技能者， 技術者の育成と溶接技能者資格付与のため尽力しているなどその業績は誠に顕著 である。

同君の溶接技術普及に関する主な業績を挙げると次のようになる.

1. 長野県内企業の溶接技術の向上，普及及び技術者，技能者の育成

長野県の公設試験研究機関長野県工業試験場の溶接技術研究職員として，試験 研究業務及び技術講習会, 巡回技術指導等を通じて県内企業へ溶接技術の普及,

向上及び技術者，技能者の育成を図った。また，長年にわたり，長野県と（社）日 本溶接協会長野県支部主催による長野県溶接技術コンクールの開催を支援し，（社）日本溶接協会平成 10 年 10 月全国溶接技術競技会長野大会の開催では, 地元として多大な貢献をし長野県の溶接技術の普及, 向上に 大きな貢献をした。

2. 溶接学会東部支部活動の業績

溶接学会東部支部長野地区委員会事務局を，昭和 53 年 4 月〜平成 19 年 7 月まで務め，この間，長野地区 主催の講習会，学術交流会等を企画・実施した。特に，昭和 55 年度および平成 19 年度秋季全国大会（長野大 会）では東部支部と連携し，長野県工業試験場あるいは業界・学協会の中核メンバーとして大会諸事業の立 案，遂行を担当して大会を盛会に導くなど大いに尽力・貢献した.

\section{東海支部}

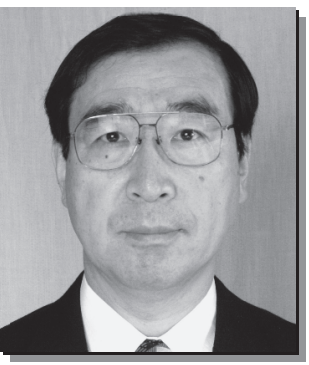

松 永 憲 一 氏 昭和 23 年 9 月 12 日生 国立大学法人 名古屋大学 全学技術センター 技官
松永憲一君は工業高等学校卒業後，42 年間の永きにわたり，名古屋大学工学部 の金属学科, /物理学科/マテリアル理工学専攻の溶接研究室 (益本研究室, 篠田研 究室, 沓名研究室) の文部技官として，アーク溶接，摩擦圧接，レーザ加工技術な どの溶接工学の研究および教育に携わり, 教職員, 学部学生および大学院学生へ の技術教育並びに研究支援を行ってきた。その間，各種材料の溶接技術，溶接性 試験ならびに溶接加工に携わり, 新溶接技術の開発, 溶接部の疲労強度改善およ び溶接アルゴリズムの確立などの研究開発にも技官として大きく貢献した.

例えば，小型平面曲げ疲労試験機，独自の小型凝固割れ試験機など試験装置の 試作・開発にも貢献した。学生への工作実習, 学生実験の補佐, 創造工学センタ 一でのものづくり公開講座などの教育にも携わり，溶接を基礎とするものづくり 教育に寄与した。

また，上記研究室で昭和 49 年から実施されてきた JICA (国際協力機構) 中部国 際センターの「溶接技術集団研修コース」の名古屋大学での研修にも 35 年間にわ たり携わり，340 名余の開発途野上国の溶接技術者の溶接技術教育に貢献した功績

も大きい.

さらに，日本非破壊検査協会中部支部の実施する非破壊検査技術者の教育にも長年携わり，溶接部の品質 管理に関する技術普及にも貢献した。

以上のように，同君が長年に亘り，溶接技術の教育，研究開発の支援および技術普及の活動を通して溶接 技術の普及・発展に貢献した功績は顕著である。 


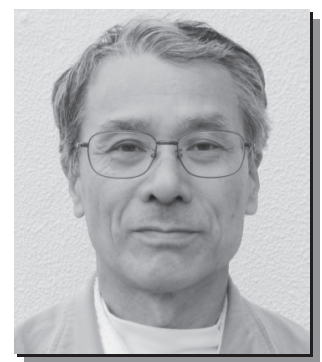

松 岡 勉 氏 昭和 26 年 5 月 10 日生 (株) IHI 愛知工場製造部 工務 $\mathrm{G}$
松岡勉氏は, 昭和 45 年以来石川島播磨重工業株式会社（現 株式会社 IHI）に勤 務し, 自動溶接技術の実用化, 現場への定着, 溶接技能者の教育に携わり, 数々 の業績を上げた。また学協会活動を通じ溶接技術の普及にも尽力した. 主な業績 は次の通り。

(1)自動溶接の導入・開発と現場への定着

入社以来職業訓練所を経て電気溶接工として船舶製造現場を経験し, 大型新造 船工場に配属されてからは, 自動溶接の導入に携わり溶接条件の絞込みなどに能 力を発揮し, 現場への定着に成功した.

具体的には，エレクトロガス溶接法にて，固定式裏当材を併用した片面摺動銅 当金方式による船側板の突合溶接を実用化した。引き続き船首尾の曲がり外販に も董当材と摺動銅当金の改良により画期的な適用実用化に成功した。またその後 は, $\mathrm{T}$ 型部材 (トランス材, ロンジ材) の突合せ溶接において, 垂直材には消耗 ノズル式エレクトロスラグ溶接を，水平材には $\mathrm{CO}_{2}$ 片面自動溶接を採用し完全自

動溶接化を造船界初の試みとして実用化し完成させた.

(2)溶接技能教育への貢献

平成 1 年からは現場から管理部門に転向し溶接技能者の育成に努めた。とくに半自動溶接の導入のため訓 練所の設備充実, 訓練計画を行い自ら指導員となって半自動溶接の適用拡大につとめた. 現在ではグラビチ イ溶接に代わり造船溶接の主力となっている.

その半自動溶接では, 優秀な技能者を育てて, 全国コンクールでは平成 10 年以降半自動溶接の部で 2 度の 3 位入賞をはたしており，この地方でのリーダ的存在となっている.

近年の産業構造の変化にともない, 半自動溶接の技術移転にも努力し, 新興の自動車・輸送機メーカを指 導し技術の普及に貢献した。現在ではそれらのメーカが全国コンクールの最優秀賞を勝ち得ている.

(3)学協会での活動

同氏は平成 9 年度から 20 年度まで日本溶接協会愛知県支部が主催する愛知県溶接技術競技会の審査委員を 勤め，かつ同主催による溶接技術交流会の指導員を長年引き受け愛知県下の溶接技術の向上に貢献した.

また，溶接協会中部地区支部委員会主催（溶接学会後援）によるHUBTEC 2005 -レーザ溶接総合技術展に て同氏は「技能教育」について実演を行い溶接技能教育の普及に貢献した.

さらに同氏は愛知県支部が企画した JIS 溶接技術検定 DVD ビデオの製作に協力し全 8 巻を完成させた. 中 でもステンレス溶接編 2 巻は直接担当し TIG, MIG, MAGの溶接技能を映像化した。これは出版社より市 販され好評を博し技能の伝承に貢献している.

\section{関西支部}

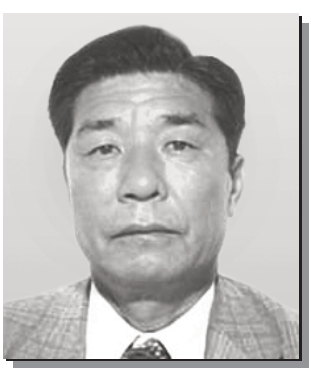

北村進 氏 昭和 11 年 5 月 18 日生 元(社)日本溶接協会関西地 区溶接技術検定委員会 元溶接技術検定評価員
候補者は 1961 年に川崎車輌株式会社（現川崎重工業(株車両カンパニー）に入社， 鉄道車両用台車枠及び高圧容器などの溶接組立に従事するとともに溶接工法の開 発に参画し，当該製品の品質·生産性向上に尽力した。その後，1994 年からは (社) 日本溶接協会関西地区検定委員会に出向し，2006 年まで溶接技能者認証試験の検 定評価員として公正な試験運営・評価に貢献した．以下に主な業績を挙げる.

・鉄道車両におけるアルミニウム合金のアーク溶接や抵抗スポット溶接の施工法 の確立に尽力し，その成果は国内初のアルミニウム製 200 系新幹線車両の製造 に生かされた。これらの功績により，1989-1990 年に科学技術長官賞，兵庫県知 事賞等を受賞した.

・生産現場における各種技量の指導とともに溶接技量向上に努めた。全国軽金属 溶接技術競技会において, 優勝を含む 13 名の入賞者を輩出するなど, 多くの優 秀な溶接士を育成し, 後進の指導に大きく貢献した.

- (社) 日本溶接協会関西地区溶接技術検定委員会に所属し，2001 年度からスター 卜したJAB (日本適合性認定協会) 認定による溶接要員認証システムへの準備・ 移行，その運営ならびに試験・評価において，多大の貢献をした. 


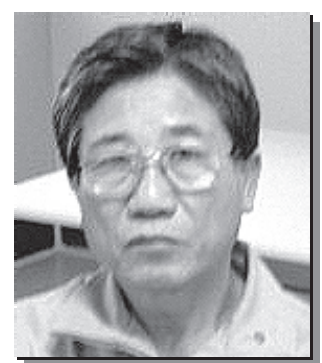

大西好秋 氏 昭和 25 年 10 月 26 日生 (株コマツ大阪工場工師長

大西 好秋氏は昭和 44 年に当社に入社し, その後一貫して, 建設機械構造物の溶 接作業に従事してきた。その間，技能研鑽に努め卓越した技能，技術を有し幾多 の工夫，改善を行い，下記の業績を挙げた.

・昭和 51 53 年に社内溶接技能競技大会で優勝.

・ブルドーザー・油圧ショベルなどあらゆる建設機械のもの作りに携わってきた 経験を生かし，新規開発車の生産性検討から治具製作迄幅広く製造に携わり， 工程設計や製品の改善を実施し，品質面においては，特に溶接構造部品の耐久 性，信頼性向上を図り，世界に誇れる建設機械の製造に大きく貢献した.

・ロボット溶接やレーザーなど新技術にも積極的に取り組み，自身の持つノウハ ウをロボット溶接条件に折込，生産性・品質向上に貢献した.

・班長や職場長に任用された後は，その溶接技術を後進に伝承するとともに，全 社の溶接部門の責任者として，溶接基本作業書及び溶接基本 DVD の製作を行 い，社内のみならず海外現地工場や地域サプライヤーも含めた幅広い人材育 成・溶接技術向上に取り組み数多くの溶接技能者を育ててきた.

・JIS 溶接検定の評価員として後進の技術指導に当たるとともに平成 10 年から国家技能検定（鉄工構造物）大 阪府の主任検定員としても地域の溶接技術レベルの向上に貢献している。

・平成 10 年職業能力開発協会により高度熟練技能者（溶接）の認定を受けるとともに，12 年大阪府により 「なにわの名工」を受賞をしている.

以上のことから，大西好秋氏は溶接技術の普及に関して大きな功績があった.

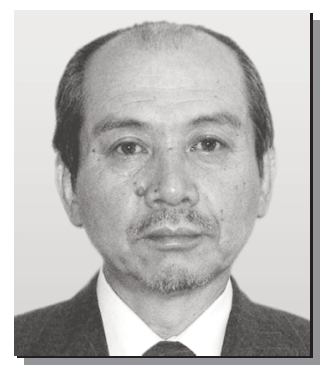

松原輝彦氏 昭和 28 年 6 月 15 日生 住友金属工業(侏) 総合技術研究所物性・分析 開発研究部業務主任
松原輝彦君は昭和 47 年に奈良県立御所工業高校を卒業後, 直ちに住友金属工業 に入社, 中央技術研究所溶接研究室に配属された。以来 30 年以上に渡り鉄鋼材料 の溶接技術に関する研究開発業務に従事し, 以下の研究推進に顕著な功績を挙げ た。

1）低炭素鋼溶接金属の勒性改善に関する研究

2）低炭素鋼溶接熱影響部の勒性改善に関する研究

3）鉄鋼材料と異材の接合・溶接方法に関する研究

特に鉄鋼材料と異材の接合溶接に関しては平成 10 年に「薄板チタンクラッド鋼 の製造・施工技術の考案」にて，職域における創意夫者表彰：兵庫県知事賞を受 賞，平成 11 年に同案件にて科学技術庁長官賞を受賞し，その功績が認められてい る。

またこの間，後進の育成にも注力し，社内教育制度として実施される溶接技術研 修会の実習担当講師として，延べ 400 名以上の研修生に溶接実技面からの指導を 行ってきた。

さらに，平成 14 年から 17 年の 4 年間に渡り，溶接学会関西支部開催行事の運営実務に尽力するなど支部 運営にも多大な功績が認められた。

以上のように，松原輝彦氏の長年にわたる溶接技術の研究・開発に対する貢献および溶接技術普及・発展 のための啓蒙に寄与した功績は誠に顕著である. 


\section{中国支部}

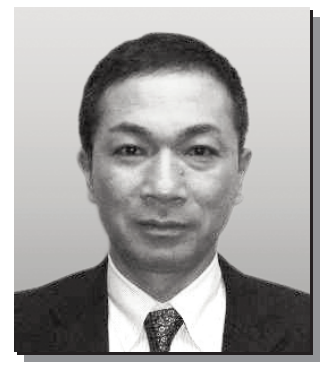

松嵪晋一 氏 昭和32年12月21日生 (株アイ・エイチ・アイマリン ユナイテッド呉工場工作部 部長

及に貢献した。

また現在, 溶接学会中国支部商議員, 広島県溶接協会副会長を務め学協会活動にも活躍中である.

以上のように，同氏が溶接技術の開発，普及に貢献した功績は顕著である.
松㟝晋一氏は昭和 57 年東北大学大学院工学研究科金属加工学専攻博士前期課程 を修了後, (株)石川島播磨重工業 (現(株IHI) に入社し, 新造船製造工程における溶 接法適用計画, 溶接機械化, 船体ブロック自動化組立ラインの計画・建設を担当, 造船溶接の高能率化, 高品質化に寄与した。

平成 14 年, 船舶海洋事業の会社分割に伴い(侏アイ・エイチ・アイ マリンユナイ テッドに移籍, その後も造船現場に在り, 造船用鋼材の高強度化に対する対応, 溶接機械化の拡大，溶接技能の維持・向上に尽力して来た.

その主な業績を挙げると次の通りである.

1） LPG 船用低温用 TMCP 鋼に対する大入熱溶接法適用の確立

2）船体ブロック自動化組立ラインと溶接自動化装置の開発

3）超大型コンテナ船用高強度鋼材に対する溶接法適用の確立

4）造船現場における溶接技能の伝承と技能者育成の取り組み

種々の講習会, セミナーにおいても造船における溶接自動化事例, 溶接技能伝 承の取り組みについて紹介するとともに, 見学会の受け入れを通し溶接技術の普

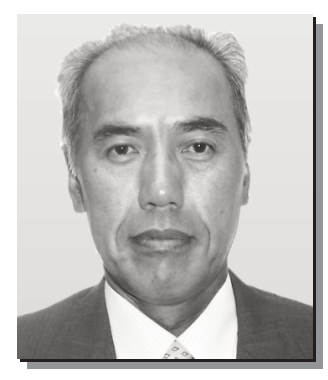

明 賀 俊 治 氏 昭和 32 年 5 月 11 日生 バブコック日立(株) 吳事業所員 Babcock-Hitachi (Philippines) Inc.出向中
明賀俊治氏は昭和 55 年 3 月大阪大学工学部溶接工学科卒業，同年 4 月バブコッ ク日立(株)吳工場（現在は呉事業所）に入社，製造部に配属され，主としてボイラ耐 圧部, 原子炬圧力容器, 化学プラント機器の溶接生産技術, 溶接機器の開発に深 く関与し, 高い信頼性の要求される高温, 高圧機器の溶接技術の進歩, 発展に大 きく寄与した。特に下記の技術開発に関しては内外より高い評価を得ている.

（1）ホットワイヤ TIG 溶接において，ワイヤ加熱電流にパルス状の電流を採用す る方法を開発し, 同溶接法の作業性を飛躍的に改善させる技術を開発した. これにより, ホットワイヤ TIG 溶接法の用途は大幅に拡大し, 特に, 大径厚 肉配管に適用している狭開先ホットワイヤ TIG 溶接では，材質を問わず高能 率，高品質を実現することが可能となった。

(2) BWR 型原子炉圧力容器の内底部に取り付けられるノズルは, 開先形状が 3 次 元状であり，溶接自動化が困難であったが，3 次元駆動の自動溶接装置を開 発し，世界で初めてこれを実機に適用した。

（3）狭ピッチで並んでいるボイラ水壁管の突合せ溶接は, 自動化が困難であるこ とから, 手動溶接で施工されていたが，管の間隔が $17 \mathrm{~mm}$ で並ぶ水壁管の突 合せ溶接を自動で行う溶接装置を開発し，海外現地で適用した。

特に，ホットワイヤ TIG 溶接法の開発では，第 19 回日本溶接協会技術賞 (昭和 63 年度), 平成 15 年度溶 接学会論文賞を受賞するなど溶接技術の開発及び普及に貢献した。また， 2007 年 4 月からは, 海外子会社で ある Babcock-Hitachi (Philippines) Inc. に出向し，フィリピンでの溶接技術の指導，普及にも多大な貢献を している.

以上のように，明賀俊治氏の長年にわたる溶接技術の発展・普及に貢献した功績は誠に顕著である. 


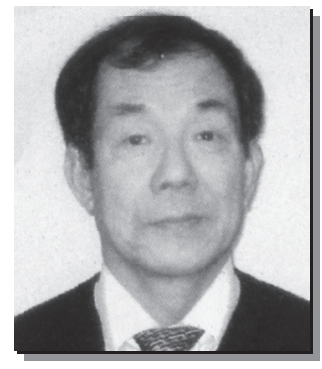

栗 田 啓二朗 氏 昭和 18 年 9 月 1 日生 愛媛県産業技術研究所 技術開発部 嘱託研究員
栗田啓二朗氏は, 昭和 45 年に愛媛県総合化学技術指導所に入庁，機械金属部門 に研究員として配属され, 以来溶接部の $\mathrm{X}$ 線作業主任者, 超音波探傷検査技術者 の資格を取得し, 溶接製品の非破壊検査を通じて, 県内企業の溶接品質の向上に 貢献してきた。圧力容器溶接部の X 線フィルム撮影から現像まで自ら行い，県内 製造業者の検査部門を強力にバックアップしてきた。また，鋳造技術や金属の化 学成分分析にも尽力し, 自ら溶解炉を操作して鋳造実験を行ったり, 超音波探傷 装置による黒鉛球状化率測定や，固体発光分析及び炭素硫黄同時分析など，分析 分野でも大きな功績を残してきた。

平成 3 年からは，愛媛県工業技術センターの機械電子室長として，愛媛県溶接 技術コンクール審査委員を歴任し，愛媛県で行われた平成 12 年度の溶接コンクー ル全国大会では, 県関係の中心的役割ほ果たした。さらに, 溶接学会四国支部の 幹事にも就任し，幅広く溶接技術の普及に尽力してきた。

現在平成 20 年度より愛媛県産業技術研究所の嘱託研究員として, 技術相談, 依 頼試験等の面で溶接技術の普及を中心に幅広く活躍している. 


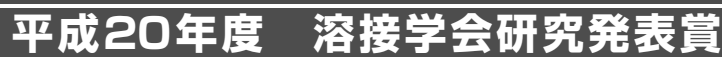

溶接学会研究発表賞は, 平成 6 年に創設され, 全国大会研究発表において, 発表内容及び発表の仕方の両 者が優れた 35 才以下の研究発表者に対し，会長から贈られます。

\section{春季全国大会}

1. 発表題目：Fe-36\% $\mathrm{Ni}$ 合金の自動 GTAW 溶接部斑点形成に関する研究 (II) 一溶接部斑点形成に及ぼす溶接変数の影響一
発表 者:
大于造船海洋 研究所 李
熙 根 君

2. 発表題目：レーザ圧接された亜鉛めっき鋼板とアルミニウム異材接合界面の微細組織観察

発 表 者: 阿南工業高等専門学校 西 本 浩 司 君

3. 発表題目：溶接法が異なる場合の入熱パラメータと角変形の関係に関する一考察

発表 者:

大阪大学 岡 野 成 威 君

4. 発表題目：溶接アークの磁気的制御に関する研究 (第 2 報)

発表者:

大阪大学大学院 野 村 和 史 君

\section{秋季全国大会}

1. 発表題目：自動車用鋼板のスポット溶接継手強度に及ぼす塗装焼付け熱履歴の影響
発表 者:
住友金属工業侏，岡 田
徹 君

2. 発表題目：FSM による腐食・減肉の検出と監視
発表 者:
珠アトラス 奥健太郎 君

3. 発表題目：プラズマ GMA 溶接システムの開発
発表 者:
(㧣ダイヘン 小 野 貢 平 君

4. 発表題目： $\mathrm{Ba}_{0.77} \mathrm{Sr}_{0.23} \mathrm{TiO}_{3}$ の誘電特性に及ぼす $\mathrm{BaHfO}_{3}$ 添加量の影響と薄膜化

発表者:

愛媛大学大学院 黒 木 義 博 君 


\section{平成20年度 溶接学会シンポジウム賞}

溶接学会シンポジウム賞は，平成 7 年度に創設され，溶接学会の研究委員会が企画・運営し，溶接学会が 主催し規定に定められた一定の基準を充たすシンポジウムにおいて発表される論文の中で，学問上・技術上 優秀と認められる論文の著者に対し，会長から贈られます。

エレクトロニクスにおけるマイクロ接合・実装技術シンポジウム（Mate 2009）

\section{Mate 2009 優秀論文賞}

$\lceil\mathrm{Cu}$ コア低 $\mathrm{Ag}$ 系 $\mathrm{Sn}-\mathrm{Ag}-\mathrm{Cu}$ はんだボールのはんだ接続信頼性」 若野基樹君，板橋武之君，千綿伸彦君，藤吉 優君（日立金属(侏) 谷江尚史君（株）日立製作所）

\section{Mate 2009 研究奨励賞}

「シミュレーションによるチップ部品のはんだ凝固形状の検討と疲労寿命への影響」

山中 哲君 $(F D K($ 秼)

「ロジンと鉛フリーハンダ用金属との反応の時間・温度依存性」

久保夏希君（荒川化学工業(侏)） 


\section{平成20年度 溶挍学会授学裳}

溶接学会奨学賞は平成 9 年 12 月に創設され，溶接・接合分野へのより強い関心を促し，次世代の溶接・接 合研究者，技術者としての発展を期待し，人格・学業ともに優れた学生に贈られます.

各支部の推薦に基づき，平成 19 年度溶接学会を授賞されました方々は次のとおりです.

\section{北海道支部}

「発熱反応を利用した超硬合金の省エネ不製法と金属部材への同時接合」

小鴆 佳介君 北海道大学大学院工学研究科修士課程材料化学専攻 2 年

\section{東北支部}

「安定化オーステナイト系ステンレス鋼の粒界工学制御」

佐藤 信也君 東北大学大学院工学研究科材料システム工学専攻博士前期 2 年

\section{東部支部}

「超音波振動付与によるフェライト系ステンレス鋼溶接部の結晶粒の微細化」

益子 拓樹君 新潟大学大学院自然科学研究科材料生産システム専攻博士前期課程 2 年

「ガス減圧と動的破壊現象を練成した高圧ガスパイプライン高速延性き裂伝播シミュレーションモデルの開 発」

三澤慧君 東京大学大学院工学系研究科システム創成学専攻修士課程 1 年

「パルス YAG レーザによる純チタンとアルミニウム合金の重ね溶接性に及ぼすインサート材の影響」

\section{東海支部}

渡邊＼cjkstart汗君 日本大学大学院生産工学研究科機械工学専攻博士前期課程 2 年

「コンデンサー放電式パーカッション溶接継手の強度におよぼす溶接条件の影響」

岡本 圭右君 三重大学大学院工学研究科機械工学専攻材料機能設計研究分野

「摩擦攪拌作用を用いた異種金属材料重ね継ざ手の創製ならびに継ざ手特性の評価」

\section{関西支部}

宮川 堅君 豊橋技術科学大学大学院博士後期課程 2 年接合加工研究室

「有限要素法による摩擦圧接中の摩擦トルク·圧接面温度解析手法の検討」

井上 晴雄君 兵庫県立大学大学院工学研究科博士前期課程機械系工学専攻 2 年次

「高耐食ニッケル合金の溶接性評価」

野本 裕己君 大阪大学工学部応用理工学科マテリアル生産科学科目

「単結晶 $\mathrm{GaN} / \mathrm{Ti}$ 薄膜ナノ界面構造解析とその特性評価」

松本 倫幸君 大阪大学大学院工学研究科マテリアル生産科学専攻

「TiNi 合金細線のマイクロ抵抗溶接」

森川 滋君 兵庫県立大学大学院材料研究科物質系工学専攻

「銀ナノ粒子を用いた接合プロセスの開発」

巽裕章君 大阪大学大学院工学研究科マテリアル生産科学専攻

「溶接部近傍に強度不均質を持つ円筒配管溶接継手の変形強度特性」

北野 萌一君 大阪大学工学部応用理工学科マテリアル生産科学科目

\section{中国支部}

「薄板構造の溶接変形防止に関する研究」

\section{九州支部}

吉村 正彦君 近畿大学大学院システム工学研究科博士前期課程 2 年

「突合せ多層溶接により生じる各パスごとの溶接変形とその特徵」

今村 博之君 九州工業大学大学院工学研究科物質工学専攻博士前期課程 2 年

「極厚高張力鋼板溶接継手部の破壊勒性評価」

吉本 浩輔君＼cjkstart長崎総合科学大学工学部機械工学科 4 年生 


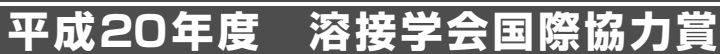

溶接学会国際協力賞は，平成 14 年 3 月 20 日に創設され，規定により，本会の国際活動事業の目的を遂行 するにあたり，多大の貢献をした方（個人会員）に授与され，総会にて公知されます.

（勤務先は開催時の所属先略称）

\section{第 8 回国際シンポジウム}

青木 満 (東電), 浅井 知 (東芝), 阿部信行 (阪大), 阿部浩也 (阪大), 稲垣正壽 (日立), 石川 忠 (新日鐵)，小川和博（住金)，井上正二(日新製鋼)，上玉利康博（松下溶接システム)，上西啓介 (阪大), 大畑 充 (阪大), 小川和博 (住金), 片山聖二 (阪大), 鴨 和彦 (三菱重工), 堅田寛治 (コマッ), 川人洋 介 (阪大), 金 裕哲 (阪大), 菊野智教 (ダイキン), 北側彰一 (日造), 黑川剛志 (タセト), 近藤正恒 (ト ヨ夕), 粉川博之 (東北大), 小関敏彦 (東大), 久保尚重 (大阪ガス), 興石房樹 (神鋼), 里中 忍 (熊大), 崎野良比呂（阪大)，佐藤嘉洋（大府大)，佐野智一 (阪大)，柴柳敏哉（阪大)，鈴村暁男（東工大)，高橋 誠（阪大), 田代真一 (阪大), 塚本雅裕 (阪大), 福本信次 (兵庫県立大), 荻原寛之 (阪大), 桐原聡秀 (阪 大), 西川 宏 (阪大), 寺崎秀紀 (阪大), 津村卓也 (阪大), 古賀信次 (川重), 柴原正和 (大府大), 田崎 利和 (特殊電極), 高橋康夫 (阪大), 寺崎俊夫 (九工大), 中村照美 (物材研), 名山理介 (三菱重工), 中山 繁 (川重), 串田守可 (栗本鉄工), 中里敏雄（ホンダエンジ）, 平岡和雄 (物材研), 廣瀬政義 (萑原), 藤本 公三 (阪大), 望戸 実 (東京大学ものづくり経営研究センター), 護 雅典 (竹中工務店), 森 裕章 (阪 大), 村山雅智 (JFE エンジ), 森安雅治 (三菱電機)，松枝啓之（関電），椋本厚司（ダイハッ）, 藤 雅雄 (日鉄住金溶接)，麻 寧緒（日本総研ソリューションズ)，森 清和（日産），三上欣希（阪大），望月正人 (阪大), 安田功一 (JFE スチール), 安田 修 (高田機工), 山本 光 (日立建機), 山根 敏（埼玉大） 


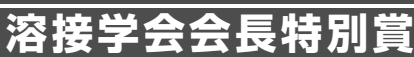

溶接学会会長特別賞は，平成 21 年 3 月 27 日に創成され，規定により，本会の事業の目的を遂行するにあ たり多大な貢献をした方（個人）に贈られます。

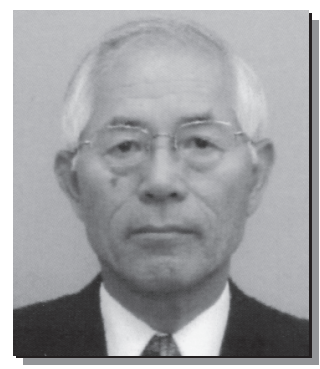

山本英幸君

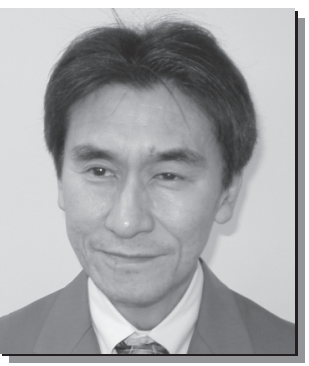

中 西 保 正 君

山本英幸君

昭和17年10月 11 日生

昭和 40 年 名古屋大学工学部応用物理学科卒

昭和 40 年 大阪変圧器(株)（現 (株) ダイヘン） 入社

平成11年 (株) ダイヘン取締役 溶接メカトロ事業部長

平成13年 同社取締役常務執行役員 溶接メカトロカンパニープレジデント

平成15年 同社取締役常務執行役員

平成17年 同社顧問，ダイヘン溶接メカトロシステム(株) 代表取締役社長

現在に至る

中西保正君

昭和 24 年 3 月 18 日生

昭和 49 年 3 月 31 日 大阪大学大学院工学研究科修士課程修了 (溶接工学専攻)

同年 4 月 1 日 石川島播磨重工業(株)（現，(株) IHI）入社，技術本部・溶接セン

ター・溶接第一実験部配属

～所属名変更：溶接研究所・第一実験部 $\rightarrow$ 技術研究所・溶接第

一\&第二研究部 $\rightarrow$ 技術研究所 $\cdot$ 接合研究部 $\rightarrow$ 技術研究所 $\cdot$ 接合 部

平成 2 年 7 月 1 日 技術開発本部・技術研究所・接合部課長

平成 7 年 7 年 1 日 技術開発本部・生産技術開発センター・生産技術開発部・接合 加工技術加工グループ長 (担当課長)

平成10年 1 月 同・担当部長代理

平成11年 7 月技術開発本部・生産技術センター・生産技術開発部次長

平成12年 7 月 技術開発本部・生産技術センター・生産技術開発部部長

平成15年 7 月 技術開発本部・生産技術センター副所長

平成17年 7 月 同（兼）株式会社アイテック (現，(株) IHI テクノソリューショ ンズ）・取締役

平成18年 4 月＼cjkstart技術開発本部・技監

平成19年 4 月 株) IHI・理事 /技術開発本部・技監 (兼) 株式会社 IHI テクノソ リューションズ・取締役

現在に至る

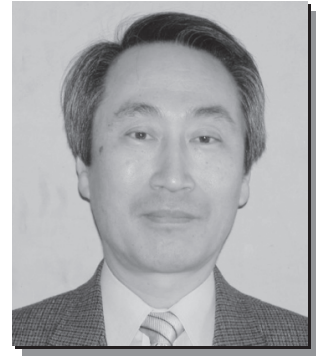

平田好 則君

平田好則君

昭和 26 年 1 月 19 日生

昭和 49 年 3 月 大阪大学工学部溶接工学科卒業

昭和 51 年 3 月 大阪大学大学院工学研究科溶接工学専攻修士課程修了

昭和 51 年 4 月 日立造船(株)入社 (桜島工場)

昭和 53 年 8 月 同上退社

昭和53年 9 月 大阪大学助手 (工学部溶接工学科) 任官

昭和 62 年 3 月 工学博士 (大阪大学)

平成元年 4 月 大阪大学講師 (工学部生産加工工学科)

平成 7 年 4 月 大阪大学助教授 (工学部生産加工工学科)

平成 9 年 4 月 大阪大学大学院助教授 (工学研究科知能機能創成工学専攻)

平成16年 4 月 大阪大学大学院教授 (工学研究科マテリアル生産科学専攻), 現在に 至る. 


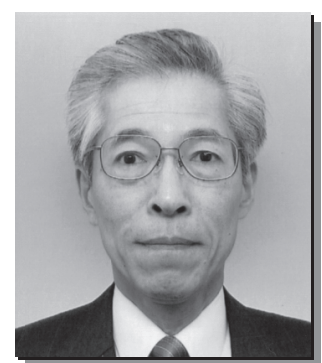

村 川 英 一 君

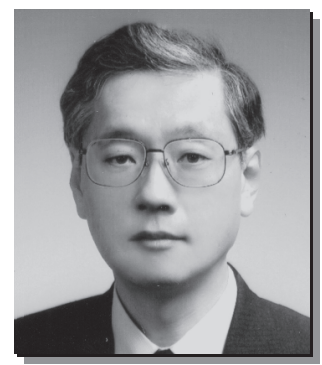

寸田一幸君

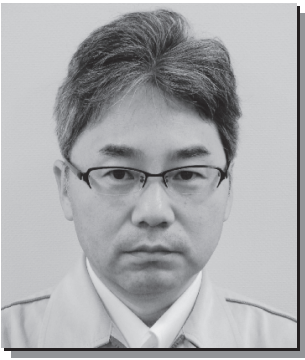

上山智之君

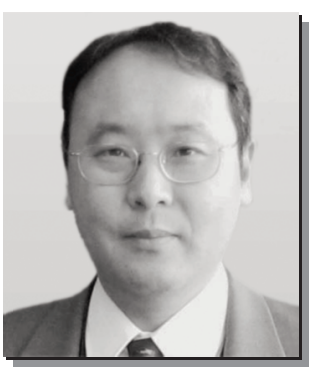

田中学君

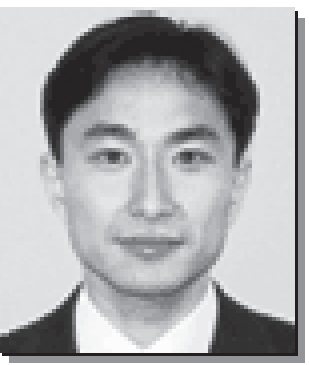

芹 澤

村川英一君

昭和 26 年 3 月 15 日生

昭和 48 年 3 月 大阪大学工学部造船学科 卒業

昭和 50 年 3 月 大阪大学大学院工学研究科 (造船学専攻) 修士課程修了

昭和53年 9 月 米国ジョージア州立工科大学 博士課程修了 (Ph. D)

昭和53年11月 米国ジョージア州立工学大学研究員

昭和55年 4 月 (株)日立製作所日立研究所研究員

昭和 58 年 2 月 大阪大学溶接工学研究所助手

昭和 62 年 4 月 大阪大学溶接工学研究所助教授

平成 13 年 3 月 大阪大学接合科学研究所教授 現在に至る

才田一幸君

昭和34年11月 27 日生

昭和58年 3 月 大阪大学工学部溶接工学科卒業

昭和 60 年 3 月 大阪大学大学院工学研究科溶接工学専攻前期課程修了

昭和 60 年 4 月 大阪大学工学部助手

平成 3 年 2 月 学位 (工学博士) 取得

自平成 3 年 4 月

至平成 4 年 5 月 この間カナダ・トロント大学客員研究員 (冶金・材料科学科)

平成 8 年 7 月 大阪大学工学部講師

平成 9 年 10 月 大阪大学工学部助教授

平成 10 年 4 月 大阪大学大学院工学研究科助教授

自平成16年 8 月

至平成16年 9 月 この間フィンランド工学研究センター (VTT) 客員研究員

平成19年 4 月 大阪大学大学院工学研究科准教授 至現在

上山智之君

昭和 36 年 5 月 12 日生

昭和 62 年 3 月 大阪大学大学院溶接工学専攻修了

同年 4 月 (株)ダイヘンに入社 溶接機事業部研究開発部配属

平成 5 年 8 月 ダイヘンヨーロッパ $\mathrm{GmbH}$ 出向

平成10年 7 月 同社 溶接機事業部技術部 加工プロセスグループ長

平成18年 3 月 大阪大学 博士 (工学)

同年 7 月 同社 溶接機事業部第二技術部 部長 現在に至る

田中 学君

昭和 42 年 4 月 30 日生

平成 2 年 3 月 大阪大学工学部溶接工学科卒業

平成 4 年 3 月 大阪大学大学院工学研究科溶接工学専攻博士前期課程修了

平成 4 年 4 月 大阪大学溶接工学研究所 助手

平成15年 4 月 大阪大学接合科学研究所 助教授

平成 20 年 2 月 大阪大学接合科学研究所 教授 現在に至る

\section{芹澤 久君}

昭和 43 年 8 月 21 日生

平成 4 年 3 月 東京大学工学部材料学科 卒業

平成 6 年 3 月 東京大学大学院工学系研究科材料学専攻修士課程 修了

平成 9 年 3 月 東京大学大学院工学系研究科材料学専攻博士課程 修了

同年 4 月 大阪大学接合科学研究所 助手

平成15年 4 月 大阪大学接合科学研究所 助教授 現在 (准教授)に至る 


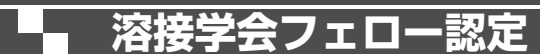

溶接学会フェローは，平成 15 年 10 月 8 日に創設され，溶接・接合に関する工学・技術と社会および本会 の発展に顕著な貢献をなされた方に溶接学会フェローの称号をお贈りし, 会員の地位向上・国際活動をより 円滑にし，あわせて本会の一層の活性化をはかることを目的としております。

各支部長，各種研究委員会委員長及び理事からの推萀に基づいて審査し，第 77 回通常総会において認定証 を贈呈しました。

(入会年月順)

浅井 良彦君堀井 行彦君和田 宏一君難波 圭三君

平岡 和雄君黒川 剛志君奥本 泰久君



浅 井 良彦君



平 岡 和 雄 君

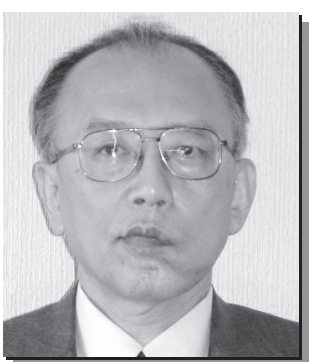

堀井行彦君

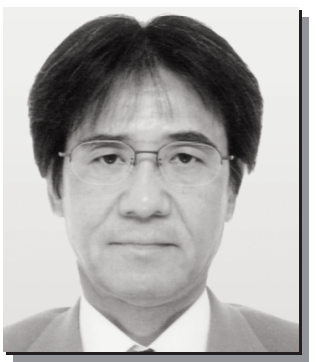

黒 川 剛志君

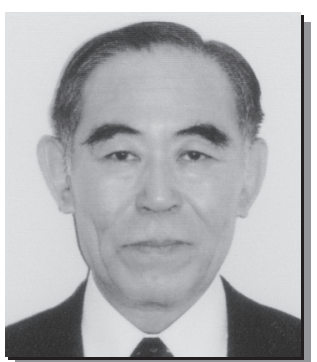

和田宏一君

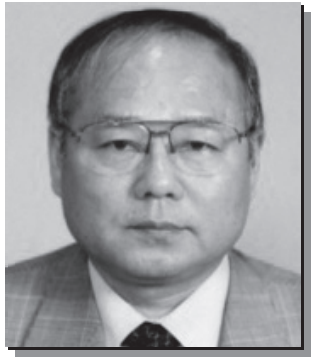

奥 本 泰 久 君

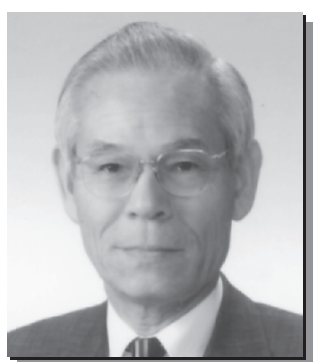

難 波 圭 三君 


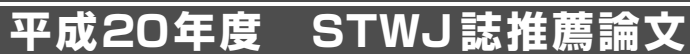

STWJ 誌との提携により，本会よりSTWJ 誌へ推薦された論文は次のとおりです.

1.「アルゴン GTA における非平衡プラズマ特性の電流值依存性」Ｎo. 2001

田代真一 (大阪大学)

岩尾 徹 (武蔵工業大学),

稲葉次紀 (中央大学)

Anthony B. MURPHY (CSIRO)

(論文集 26 巻 1 号)

2.「ニッケル基合金の急速加熱・加圧による形成組織 - Inconel 718 合金の摩擦圧接部の特性とその支配因

子-」 No. 2005

王＼cjkstart洪杰，池内建二，高橋 誠（大阪大学）

池田昭夫（エムアイエヌコンサルタント(姝)

(論文集 26 巻 2 号)

3.「ニッケル基合金の摩擦圧接部に扔ける形成組織 - Inconel 718 合金の摩擦圧接部の特性とその支配因

子-」 No. 2006

王 洪杰, 池内建二, 高橋 誠（大阪大学）

有年雅敏（兵庫県立工業試験場）

池田昭夫（エムアイエヌコンサルタント(侏）

(論文集 26 巻 2 号)

4.「ニッケル基合金の摩擦圧接継手の強度および後熱処理によるその改善 - Inconel 718 合金の摩擦圧接部 の特性とその支配因子一」Ｎo. 2007

王 洪杰，池内建二，高橋 誠（大阪大学）

有年雅敏（兵庫県立工業試験場）

池田昭夫（エムアイエヌコンサルタント(侏）

(論文集 26 巻 2 号)

5.「「スンレス鋼の $10 \mathrm{~kW}$ 高出力ファイバーレーザ溶接時の欠陥形成機構と防止法」Ｎo. 2011 川人洋介，水谷正海，片山聖二 (大阪大学)

(論文集 26 巻 3 号)

6.「SUS347H 系鋼溶接金属凝固過程に打ける NbC の晶出成長挙動の解明」 No. 2023 小薄孝裕, 米村光治, 小川和博（住友金属工業(侏)

(論文集 26 巻 3 号)

7. 「赤外線二色放射測温法による溶融池表面温度測定」Ｎo. 2035

山崎 圭，山本恵理，鈴木啓一，舆石房樹（侏神戸製鋼所）

宮迴 滋，田代真一，田中 学，中田一博（大阪大学）

(論文集 27 巻 1 号) 